\title{
Minireviews
}

\section{Involvement of Activated Brain Stress Responsive Systems in Excessive and "Relapse" Alcohol Drinking in Rodent Models: Implications for Therapeutics}

\author{
Yan Zhou and Mary Jeanne Kreek \\ Laboratory of Biology of Addictive Diseases, Rockefeller University, New York, New York \\ Received October 10, 2017; accepted April 16, 2018
}

\begin{abstract}
Addictive diseases, including addiction to alcohol, pose massive public health costs. Addiction is a chronic relapsing disease caused by both the direct effects induced by drugs and persistent neuroadaptations at the molecular, cellular, and behavioral levels. These drug-type specific neuroadaptations are brought on largely by the reinforcing effects of drugs on the central nervous system and environmental stressors. Results from animal experiments have demonstrated important interactions between alcohol and stressresponsive systems. Addiction to specific drugs such as
\end{abstract}

alcohol, psychostimulants, and opioids shares some common direct or downstream effects on the brain's stress-responsive systems, including arginine vasopressin and its $\mathrm{V} 1 \mathrm{~b}$ receptors, dynorphin and the $\kappa$-opioid receptors, pro-opiomelanocortin/ $\beta$-endorphin and the $\mu$-opioid receptors, and the endocannabinoids. Further study of these systems through laboratory-based and translational research could lead to the discovery of novel treatment targets and the early optimization of interventions (for example, combination) for the pharmacologic therapy of alcoholism.

\section{Introduction}

The expanding literature has demonstrated that alcohol activates the brain's stress-responsive systems, which contributes to excessive alcohol drinking and the development of alcoholism with the relapse of alcohol use. Several reviews from 2016 to 2018 of preclinical evidence from clinical trials have provided details on other important stress-responsive systems such as corticotrophin-releasing factor, neuropeptide $\mathrm{Y}$, and glucocorticoid receptor (Koob and Mason, 2016; Mantsch et al., 2016; Blaine and Sinha, 2017; Mason, 2017; Pomrenze et al., 2017; Robinson and Thiele, 2017; Spierling and Zorrilla, 2017; Tunstall et al., 2017). The main focus in

This work was supported by the National Institutes of Health National Institute on Alcohol Abuse and Alcoholism [Grant AA021970 (to Y.Z.)], Robertson Therapeutic Development Fund at the Rockefeller University to Y.Z.) and by Dr. Miriam and Sheldon G. Adelson Medical Research Foundation (to M.J.K.).

https://doi.org/10.1124/jpet.117.245621. this mini-review is on important stress responsive systems that have yet to be reviewed such as arginine vasopressin/V1b receptors (in the section V1b Receptor and Arginine Vasopressin System) and pro-opiomelanocortin/ $\beta$-endorphin (in the section POMC/ $\beta$-Endorphin and $\mu$-Opioid Receptor System). For two other stress-responsive systems, endocannabinoids/ fatty acid amide hydrolase (Endocannabinoid System) and dynorphin/ $\kappa$-opioid receptors ( $\kappa$-Opioid Receptor and Dynorphin System), we examine controversies in the literature and the current state of the field for possible explanations (Parsons and Hurd, 2015; Chavkin and Koob, 2016; Anderson and Becker, 2017; Karkhanis et al., 2017; Tunstall et al., 2017). This mini-review provides an overview of the recent literature for these four stress-responsive systems in alcohol research, using laboratory-based animal models and clinical research to elucidate the biology of addictive diseases. We propose that translational bidirectional research will help refine future preclinical targets for the pharmacologic therapy of alcoholism.

\footnotetext{
ABBREVIATIONS: ADE, alcohol-deprivation effect; AEA, anandamide; AVP, arginine vasopressin; BNST, bed nucleus of the stria terminalis; CB, cannabinoid receptors; $\mathrm{CeA}$, central nucleus of amygdala; CNS, central nervous system; CPP, conditioned place preference; CRF, corticotrophinreleasing factor; DID, drinking-in-the-dark; eCB, endocannabinoids; eGFP, enhanced green florescent protein; FAAH, fatty acid amide hydrolase; HPA, hypothalamic-pituitary-adrenal; IA, intermittent access drinking; KOP-r, $\kappa$-opioid receptor; LY2456302, 4-[4-[(2S)-2-(3,5-dimethylphenyI)pyrrolidin-1-yl]methyl]phenoxy]-3-fluorobenzamide; MC4, melanocortin 4 receptor; MOP-r, $\mu$-opioid receptor; MSB, mesyl salvinorin B; NAc, nucleus accumbens; nor-BNI, nor-binaltorphimine; NTN, naltrexone; POMC, pro-opiomelanocortin; PVN, paraventricular nucleus; sNP, Sardinian alcohol-nonpreferring; SP, Sardinian alcohol-preferring rats; SSR149415, (2S,4R)-1-[5-chloro-1-[(2,4-dimethoxyphenyl)sulfonyl]-3-(2-methoxyphenyl)-2-oxo-2,3-dihydro-1H-indol-3-yl]-4-hydroxy-N,N-dimethyl-2-pyrrolidine carboxamide; U50,488, (trans)-3,4-dichloro- $\mathrm{N}$-methyl-N-[2-(1-pyrrolidinyl)-cyclohexyl]benzeneacetamide; URB597, [3-(3-carbamoylphenyl)phenyl] $N$-cyclohexylcarbamate.
} 
TABLE 1

Effects of AVP or V1b antagonists on alcohol-related behaviors

\begin{tabular}{|c|c|c|c|c|}
\hline Subjects & Sex & Model & Effect & Reference \\
\hline $\begin{array}{l}\text { Brattleboro } \\
\text { homozygote rats }\end{array}$ & Male & 2-Bottle choice (24 h, 2\%-10\%) & $\begin{array}{l}\text { Decrease (intake) by systemic } \\
\text { (osmotic pump) DGAVP }\end{array}$ & Rigter and Crabbe (1985) \\
\hline Rhesus monkeys & $\begin{array}{l}\text { Male, } \\
\text { female }\end{array}$ & Multiple-bottle choice $(24 \mathrm{~h}, 1 \%-8 \%)$ & $\begin{array}{l}\text { Decrease (intake) by systemic } \\
\text { (i.v.) DGAVP }\end{array}$ & Kornet et al. (1991) \\
\hline $\begin{array}{l}\text { Sardinian alcohol- } \\
\text { preferring rats }\end{array}$ & Male & 2-Bottle choice $(24 \mathrm{~h}, 10 \%)$ & $\begin{array}{l}\text { Decrease (intake and preference) } \\
\text { by systemic (i.p.) SSR149415 }\end{array}$ & Zhou et al. (2011) \\
\hline $\begin{array}{l}\text { Alcohol-dependent } \\
\text { Wistar rats }\end{array}$ & Male & Operant self-administration $(10 \%, 30 \mathrm{~min})$ & $\begin{array}{l}\text { Decrease (intake) by systemic (i.p.) } \\
\quad \text { or intracentral amygdala SSR149415 }\end{array}$ & Edwards et al. (2012) \\
\hline C57Bl/6J mice & $\begin{array}{l}\text { Male, } \\
\text { female }\end{array}$ & 2-Bottle choice ( $24 \mathrm{~h}$, every other day, $15 \%$ ) & $\begin{array}{l}\text { Decrease (intake and preference) } \\
\text { by systemic (i.p.) SSR149415 }\end{array}$ & Zhou et al. (2018) \\
\hline Humans & $\begin{array}{l}\text { Male, } \\
\text { female }\end{array}$ & $\begin{array}{l}\text { Phase } 2 \text {, double-blind, placebo-controlled, } \\
\text { randomized trial }\end{array}$ & $\begin{array}{l}\text { Decrease (intake and relapse) } \\
\text { by systemic (oral) ABT- } 436\end{array}$ & Ryan et al. (2017) \\
\hline
\end{tabular}

ABT-436, V1b antagonist; DGAVP, desglycinamide-( $\left.\mathrm{Arg}^{8}\right)$-vasopressin; SSR149415, V1b antagonist.

V1b Receptor and Arginine Vasopressin System. In the neurobiology of stress-related behaviors, increased arginine vasopressin (AVP) neuronal activity is involved in important steps in several rodent models (Griebel et al., 2002; Salome et al., 2006; Roper et al., 2011) and in humans (Katz et al., 2016; Ryan et al., 2017). Since the 1980s, evidence has emerged implicating AVP in the motivational properties of drugs of abuse (see van Ree et al., 1999). Systemic administration of desglycinamide-( $\left.\mathrm{Arg}^{8}\right)$-vasopressin (DGAVP) reduced alcohol intake in studies exploring the role of AVP in rhesus monkeys (Kornet et al., 1991), and it also decreased alcohol intake in Brattleboro homozygote rats lacking vasopressin (Rigter and Crabbe, 1985) (Table 1).

Of interest, after chronic exposure to an alcohol-containing diet, AVP mRNA levels were decreased in several stressresponsive brain regions of $\mathrm{C} 57 \mathrm{BL} / 6 \mathrm{~J}$ mice, including the paraventricular nucleus (PVN), supraoptic nucleus, and bed nucleus of the stria terminalis (BNST) (Ishizawa et al., 1990; Gulya et al., 1991; Hoffman and Dave, 1991). Further studies demonstrated a decrease of the number of AVP-immunoreactive neurons and reduction of AVP mRNA levels in the hypothalamus after chronic alcohol consumption in both humans (Harding et al., 1996) and rats (Silva et al., 2002). In humans, abnormal levels of serum and urine AVP were found during alcohol withdrawal, particularly when the symptoms were severe (Eisenhofer et al., 1985; Trabert et al., 1992).

In several selectively bred alcohol-drinking rat lines, there are higher basal levels of AVP mRNA in the PVN of Indiana alcohol-preferring rats, Sardinian alcohol-preferring $(\mathrm{sP})$ rats, and high-alcohol-drinking rats as compared with their respective alcohol-nonpreferring and low-alcohol-drinking counterparts (Hwang et al., 1998; Zhou et al., 2011). Higher basal AVP mRNA levels were also found in the medial amygdala of $\mathrm{sP}$ rats compared with Sardinian alcohol-nonpreferring (sNP) rats; chronic ( $>2$ weeks) alcohol drinking reduced the AVP mRNA levels in the PVN and medial amygdala of $\mathrm{sP}$ rats (Zhou et al., 2011). Of interest, individual differences in AVP mRNA levels are positively associated with vulnerability to high alcohol drinking in C57BL/6J mice after acute stress (Nelson et al., 2018), so more studies are needed as individual vulnerability to drug relapse during abstinence is a key feature of drug addiction (Imperio et al., 2016; Sushchyk et al., 2016).

AVP binds to two G protein-coupled receptor subtypes in the brain: V1a and V1b. Both are expressed in the extended amygdala, with high concentrations in the central nucleus of amygdala (CeA), the BNST, and nucleus accumbens (NAc) (Veinante and Freund-Mercier 1997). Specifically, V1b receptors are mostly distributed in the PVN, hippocampus, and amygdala as well as the anterior pituitary (Lolait et al., 1995; Vaccari et al., 1998; Hernando et al., 2001; Young et al., 2006). In rodent models, many studies have suggested that augmented AVP/V1b activity in the amygdala plays a critical step in the stress-related behaviors. 1) After acute stress the rat amygdala shows increased levels of extracellular AVP (Wigger et al., 2004). 2) After acute withdrawal stress from drug exposure or by foot-shock stress after drug self-administration the rat amygdala shows increased levels of AVP mRNA (Zhou et al., 2005, 2008). 3) Activation of V1b receptors is involved in anxiety-like and depression-like behaviors (Griebel et al., 2002; Serradeil-Le Gal et al., 2002; Salome et al., 2006; Roper et al., 2011). SSR149415 [(2S,4R)-1-[5-chloro-1-[(2,4dimethoxyphenyl)sulfonyl]-3-(2-methoxy-phenyl)-2-oxo-2,3dihydro- $1 H$-indol-3-yl]-4-hydroxy- $N, N$-dimethyl-2-pyrrolidine carboxamide], a highly selective nonpeptide antagonist for the $\mathrm{V} 1 \mathrm{~b}$ receptor, has anxiolytic-like and antidepressant-like properties (e.g., Overstreet and Griebel 2005).

One of the critical factors influencing individual vulnerability to drug relapse is atypical stress responsivity (Kreek and Koob, 1998; Zhou and Kreek, 2014). Using validated experimental models such as the forced swim and elevated plus maze tests, investigators have demonstrated anxiety-like and depression-like behaviors in rodents after chronic alcohol exposure, mostly during acute withdrawal (Colombo et al., 2006; Bell et al., 2012). As the high degree of anxiety-like and depression-like states is partially attenuated after voluntary alcohol drinking, rodents may drink alcohol to improve their emotional states (negative reinforcing mechanism) (Colombo et al., 2006; Bell et al., 2012; Pang et al., 2013).

In our alcohol study with $\mathrm{sP}$ rats, the V1b antagonist SSR149415 dose-dependently attenuated alcohol intake, suggesting that a $\mathrm{V} 1 \mathrm{~b}$ receptor-mediated mechanism is involved in modulating alcohol-drinking behaviors (Zhou et al., 2011). Importantly, SSR149415 reduces excessive alcohol selfadministration in alcohol-dependent Wistar rats in a dosedependent manner, without altering the alcohol drinking of nondependent rats (Edwards et al., 2012) (Table 1). Systemic administration of $\mathrm{V} 1 \mathrm{~b}$ antagonists blocks stress and drug priming-triggered seeking behavior (Zhou et al., 2008) and prevents the dysphoria induced by nicotine withdrawal (Qi et al., 2015) as well as nicotine-induced locomotor 
sensitization (Goutier et al., 2016). Therefore, the AVP/V1b system is a critical component of the negative reinforcing effects of alcohol, heroin, or nicotine, especially during drug withdrawal. In a recent phase 2 , double-blind clinical trial (Table 1), pharmacologic blockade of the $\mathrm{V} 1 \mathrm{~b}$ receptor reduced alcohol consumption and the relapse rate in alcoholdependent patients, especially those experiencing high stress (Ryan et al., 2017). As the V1b receptor is a feasible target in humans, there is translational potential for novel antialcoholism medications.

Stress increases secretion of corticotrophin-releasing factor (CRF) and AVP (the parvocellular division of the PVN) from terminals of the PVN into the pituitary portal circulation. The interaction between $\mathrm{CRF}$ and $\mathrm{CRF} 1$ receptors on corticotropes initiates the biosynthesis of pro-opiomelanocortin (POMC)derived peptides and their release from the anterior pituitary (Vale et al., 1981). AVP from the parvocellular division of the PVN activating $\mathrm{V} 1 \mathrm{~b}$ receptors in the corticotropes enhances ACTH secretion from the anterior pituitary (Lolait et al., 1995; Aguilera and Rabadan-Diehl. 2000). However, AVP neurons in the magnocellular division of the PVN project to the posterior pituitary and then release AVP into the systemic circulation in response to stress. Both $\mathrm{CRF} / \mathrm{CRF} 1$ receptor and AVP/V1b receptor systems are also mediators of the actions of central stress responsive systems, as both are widely distributed in the central nervous system (CNS) (Zhou et al., 1996; Roper et al., 2011).

Different from the hypothalamic CRF in response to acute cocaine use, several studies have shown that AVP in the PVN does not contribute to the acute stimulatory effects of alcohol on hypothalamic-pituitary-adrenal (HPA) activity (Rivier and Vale, 1988; Lee and Rivier, 1997). It is still not known whether the AVP/V1b receptor systems are specifically involved in the HPA modulation during acute or chronic withdrawal from alcohol exposure or after relapse-like drinking in rodent models, though AVP is potent modulator of HPA axis. While the activation of the PVN CRF contributes to the stimulating effect of acute alcohol on the HPA axis (e.g., Rivier and Vale, 1988), chronic alcohol exposure blunts the HPA hormonal response to alcohol, showing the development of HPA tolerance with either no change or an even decreased CRF mRNA level in the PVN (Zhou et al., 2000; Richardson et al., 2008).

Acute and protracted withdrawal from alcohol is coupled with decreased levels of both plasma corticosterone and hypothalamic CRF-like immunoreactivity in alcohol-dependent rats (Zorrilla et al., 2001). In humans, acute exposure to alcohol profoundly activates the HPA axis, and many alcoholics develop HPA tolerance after chronic alcohol exposure (Adinoff et al., 1990; Inder et al., 1995). In contrast, acute alcohol withdrawal transiently activates the HPA axis (Hundt et al., 2001; Zimmermann et al., 2003). Also, the noradrenergic system, the known key stress mediator involved in stress and anxiety responses (e.g., Tunstall et al., 2017), probably interacts with AVP and CRF systems to regulate alcohol drinking and HPA activity.

POMC/ $\boldsymbol{\beta}$-Endorphin and $\boldsymbol{\mu}$-Opioid Receptor System. In the pituitary, ACTH is produced from the anterior lobe corticotrophs, whereas $\mathrm{N}$-acetylated forms of $\beta$-endorphin and $\alpha$-melanocyte-stimulating hormone are produced in the intermediate lobe melanotrophs. In the brain, the arcuate nucleus of the hypothalamus processes POMC to produce the potent opioid peptide $\beta$-endorphin as well as $\alpha-, \beta$-, and $\gamma$-melanocortins (Ragavan et al., 1983; Rubinstein et al., 1996; Cowley et al., 2001; Romanova et al., 2015). Besides the arcuate nucleus, the POMC mRNA molecule has also been detected in much lower levels in several other mouse and rat brain regions, including the NAc, amygdala, hippocampus, and cerebral cortex (Civelli et al., 1982; Zhou et al., 1996, 2013b; Leriche et al., 2007; Bodnar, 2014; Granholm et al., 2017). Using the POMC-enhanced green florescent protein (eGFP) mice, we have found that POMC expression in POMCeGFP neurons can be visualized by GFP immunohistochemistry, and a modest amount of POMC-eGFP neurons is present in both the shell and core subregions of the NAc (Zhou et al., $2013 b)$. In the NAc, the amount of POMC mRNA is $~ 10 \%$ of that detected in the hypothalamus, and the relatively low POMC mRNA signal in the NAc is correlated with the relatively small number of POMC-eGFP neurons in POMCeGFP mice. Though alcohol drinking for more than 2 weeks increased POMC mRNA in the NAc shell (but not the core) of sP rats, it remains unclear whether the POMC mRNA in the extrahypothalamic regions (e.g., NAc shell and core) will be processed to melanocortins, $\beta$-endorphin, or other functional peptides.

In the rat anterior pituitary after acute or chronic alcohol administration, an increase, a decrease, or no change of the POMC mRNA levels as well as levels of POMC-derived peptides was reported (Gianoulakis et al., 1988; Winkler et al., 1995; Zhou et al., 2000, 2013b). Using a pituitaryspecific deletion of the POMC gene in Tpit transgenic mice, our recent study found that the pituitary POMC deficiency did not change either alcohol drinking in a drinking-in-the-dark (DID) model (with a 4-hour limited access to alcohol in the dark cycle) or an alcohol-induced conditioned place preference (CPP) in male or female mice, suggesting that the pituitary POMC cells may not involve in the rewarding action or "binge" consumption of alcohol (Zhou et al., 2017c).

In the hypothalamus, POMC mRNA levels are either increased or decreased after acute or chronic alcohol (Angelogianni and Gianoulakis, 1993; Zhou et al., 2000, 2013b; Rasmussen et al., 2002; Navarro et al., 2013). C57BL/6 mice have high basal POMC mRNA levels in the hypothalamus with a high alcohol intake or preference as compared with the alcohol-avoiding DBA/2 mice with low alcohol intake or preference (Jamensky and Gianoulakis, 1999). In parallel, we found that the sP rats have higher basal POMC mRNA levels in the hypothalamus than sNP rats; chronic alcohol drinking for more than 2 weeks resulted in further increases in the hypothalamic POMC mRNA levels in sP rats (Zhou et al., 2013b). Considering the well-established role of $\beta$-endorphin in alcohol-drinking behaviors, the genetically determined POMC expression at basal levels and in response to alcohol may contribute to the high alcohol preference and/or consumption found in $\mathrm{sP}$ rats and C57BL/6J mice.

Activation of the $\mu$-opioid receptor (MOP-r) by $\beta$-endorphin produces rewarding (Barson et al., 2011; Koch et al., 2015) and regulates NAc dopamine release (e.g., Spanagel et al., 1991). Alcohol or other drugs of abuse may release $\beta$-endorphin in the NAc (Olive et al., 2001; Marinelli et al., 2003; Roth-Deri et al., 2008), and the effects could be involved in the reinforcing actions and motivational behaviors of the drugs of abuse in rodents. Indeed, intracerebroventricular administration of $\beta$-endorphin induces CPP in rats (Amalric et al., 1987). 
TABLE 2

Effects of genetic deletion of $\beta$-endorphin, POMC, and MOP-r on alcohol-related behaviors

\begin{tabular}{|c|c|c|c|c|}
\hline Subjects & Sex & Model & Effect & Reference \\
\hline$\beta$-Endorphin KO & $\begin{array}{l}\text { Male }+ \\
\text { female }\end{array}$ & $\begin{array}{l}\text { [1] 2-Bottle choice }(24 \mathrm{~h}, 7 \%) \text {; } \\
\text { [2] 2-Bottle choice }(24 \mathrm{~h}, 10 \%)\end{array}$ & $\begin{array}{l}\text { [1] Increase (intake } \\
\text { and preference); } \\
\text { [2] No difference (intake } \\
\text { or preference) }\end{array}$ & $\begin{array}{l}\text { Grisel et al. } \\
\quad(1999)\end{array}$ \\
\hline$\beta$-Endorphin KO & Male & $\begin{array}{l}\text { [1] 2-Bottle choice }(24 \mathrm{~h}, 10 \%) \text {; } \\
\text { [2] 2-Bottle choice }(2 \mathrm{~h}, 10 \%) \text {; } \\
\text { [3] ADE }\end{array}$ & $\begin{array}{l}\text { [1] No difference (intake); } \\
\text { [2] Increase (intake); } \\
\text { [3] Increase (intake) }\end{array}$ & $\begin{array}{l}\text { Grahame et al. } \\
\text { (2000) }\end{array}$ \\
\hline$\beta$-Endorphin KO & $\begin{array}{l}\text { Male, } \\
\text { female }\end{array}$ & 2-Bottle choice (24 h, 16\%); & $\begin{array}{l}\text { Decrease (intake and } \\
\text { preference) with sex } \\
\text { difference }\end{array}$ & $\begin{array}{l}\text { Racz et al. } \\
(2008)\end{array}$ \\
\hline $\begin{array}{l}\text { Tpit KO mice with pituitary-specific POMC } \\
\text { deletion }\end{array}$ & $\begin{array}{l}\text { Male, } \\
\text { female }\end{array}$ & 1-Bottle $(4 \mathrm{~h}, 15 \%)$ in DID & $\begin{array}{l}\text { No difference in intake } \\
\text { or preference in either } \\
\text { sex }\end{array}$ & $\begin{array}{l}\text { Zhou et al. } \\
\quad(2017 \mathrm{c})\end{array}$ \\
\hline $\begin{array}{l}\text { nPE KO mice with hypothalamic-specific } \\
\text { POMC deletion }\end{array}$ & $\begin{array}{l}\text { Male, } \\
\text { female }\end{array}$ & $\begin{array}{l}\text { [1] } 1 \text {-Bottle }(4 \mathrm{~h}, 7.5 \%-30 \%) \text { in } \\
\text { DID; } \\
\text { [2] } 2 \text {-Bottle choice }(24 \mathrm{~h}, \\
\text { every other day, } 7.5 \%-30 \%) \\
\text { in IA; } \\
\text { [3] ADE }\end{array}$ & $\begin{array}{l}\text { Decrease (intake and } \\
\text { preference) in all } \\
\text { three models, with } \\
\text { sex difference }\end{array}$ & $\begin{array}{l}\text { Zhou et al. } \\
\quad(2017 \mathrm{c})\end{array}$ \\
\hline MOP-r KO & $\begin{array}{l}\text { Male, } \\
\text { female }\end{array}$ & $\begin{array}{l}\text { [1] 2-Bottle choice }(24 \mathrm{~h}, 2 \%- \\
32 \%) \text {; } \\
\text { [2] CPP }\end{array}$ & $\begin{array}{l}\text { [1] Decrease (intake) } \\
\text { with sex difference; } \\
\text { [2] Decrease }\end{array}$ & $\begin{array}{l}\text { Hall et al. } \\
\quad(2001)\end{array}$ \\
\hline MOP-r KO with striatum-specific deletion & Male & $\begin{array}{l}\text { [1] 2-Bottle choice }(24 \mathrm{~h}, 10 \%) \text {; } \\
\text { [2] 2-Bottle choice }(24 \mathrm{~h} \text {, } \\
\text { every other day, } 10 \%) \text { in IA; } \\
\text { [3] CPP }\end{array}$ & $\begin{array}{l}\text { [1] Decrease (intake } \\
\text { and preference); } \\
\text { [2] Decrease (intake } \\
\text { and preference); } \\
\text { [3] Decrease }\end{array}$ & $\begin{array}{l}\text { Ben Hamida et al. } \\
\quad(2018)\end{array}$ \\
\hline
\end{tabular}

KO, knockout; nPE, neuronal Pomc enhancers.

Consistent evidence has been provided by numerous pharmacologic studies in rodents showing that opioid antagonists reduce alcohol consumption, reward, reinstatement of seeking behavior induced by cue, and "relapse" drinking. In human alcoholics, the opioid antagonist naltrexone decreases alcohol drinking, craving, and relapse (e.g., Brown and Holtzman, 1981; Hall et al., 2001; Liu and Weiss, 2002; Kuzmin et al., 2003; Pastor et al., 2011; Lukas et al., 2013; see also reviews by Gianoulakis, 1993; Herz, 1997; Le Merrer et al., 2009). MOP-r knockout mice show a decrease in alcohol drinking or selfadministration (Roberts et al., 2000; Hall et al., 2001; Ben Hamida et al., 2017) (Table 2), which further indicates that the $\beta$-endorphin/MOP-r plays a functional role in the modulation of alcohol drinking.

POMC neurons in the hypothalamus, the main region producing $\beta$-endorphin in the brain, may contribute to alcohol consumption. It is not clear, however, whether there is an involvement of $\beta$-endorphin in regulation of alcohol drinking, as studies using $\beta$-endorphin-deficient mice have shown inconsistent results (Grisel et al., 1999; Grahame et al., 2000; Racz et al., 2008) (Table 2). A limitation of this global $\beta$-endorphin knockout mouse model is that it does not allow for clarification of which specific regions of POMC cells (e.g., hypothalamus or possible pituitary) are involved in alcoholdrinking behaviors. Recently, the neuronal Pomc enhancers (nPE1 and nPE2) that are necessary for POMC expression specifically in hypothalamic arcuate neurons have been identified. The simultaneous transcriptional interference of Pomc enhancer function by insertion of a neomycin selection cassette in the enhancer vicinity abolishes POMC gene expression in the hypothalamic arcuate nucleus of transgenic mice, while leaving normal levels of POMC expression in the pituitary cells (Bumaschny et al., 2012).

Therefore, to determine the role of hypothalamic POMC neurons in alcohol-drinking behaviors, we have used transgenic mice with a region-specific POMC deficiency resulting from selective deletion of Pomc enhancers (Lam et al., 2015). Specifically, in mice of both sexes we determined the effect of tissue-specific Pomc gene manipulation on 1) binge drinking in a DID model (Rhodes et al., 2005), 2) acquisition and escalation of excessive alcohol drinking in a chronic intermittent access (IA) model (Wise, 1973; Simms et al., 2008; Hwa et al., 2011), and 3) relapse drinking in an alcohol-deprivation effect (ADE) model (Holter and Spanagel, 1999; Heyser et al., 2003). The wild-type mice exposed to DID rapidly established stable alcohol drinking behaviors, with more intake in females, whereas the hypothalamic POMC-deficient mice of both sexes had lower alcohol intake and preference. Though the hypothalamic POMC-deficient mice showed less saccharin intake and preference than the wild-type mice, there was no genotype difference in sucrose intake or preference. After 3 weeks of IA, the wild-type mice gradually escalated to high alcohol intake and preference, with more intake in females; the hypothalamic POMC-deficient mice showed less escalation. Of interest, pharmacologic blockade of MOP-r with naltrexone (NTN) dose-dependently reduced intake in the wild-type mice but had blunted effect in the hypothalamic POMC-deficient mice. The wild-type mice of both sexes displayed significant relapse-like $\mathrm{ADE}$ drinking, with more pronounced $\mathrm{ADE}$ in females; the hypothalamic POMC-deficient mice showed no ADE in either sex. Our results suggest an involvement of neuronal $\mathrm{POMC} / \beta$-endorphin in the 
regulation of binge drinking, excessive drinking, and relapse, possibly through a hypothalamic-mediated mechanism, and with sex differences (Zhou et al., 2017c) (Table 2). Consistently, mice lacking MOP-r have shown reduced excessive alcohol drinking (Ben Hamida et al., 2017).

Consistent with previous studies in mice (Hall et al., 2001; Racz et al., 2008; Hwa et al., 2011; Yoo et al., 2012) and rats (recently reviewed by Becker and Koob (2016)), we have confirmed sex differences in alcohol drinking, with higher alcohol intake in females. The genotype differences in alcohol intake between hypothalamic POMC-deficient and wild-type mice are much greater in females than in males. The POMC deficiency affects female mice more strongly than males, suggesting that POMC may influence alcohol consumption in a sex-specific manner (Zhou et al., 2017c). Our results are in line with earlier studies that demonstrated decreased alcohol intake in $\beta$-endorphin and MOP-r knockout mice with more notable differences in females (Hall et al., 2001; Racz et al., 2008) (Table 2). Sex differences have also been observed in a human genetic study, which showed that the Pomc twomarker haplotype is associated with alcoholism only in women (Racz et al., 2008). These results also contribute to the idea of sex differences in opioid regulation of alcohol dependence (Becker and Koob, 2016).

Activation of POMC neurons affects food intake (which is increased and decreased by endorphin and melanocortins, respectively) especially at the onset of the dark cycle in mice (Mercer et al., 2013), so we purposely monitored drinking activity in the IA model during the 24-hour cycle with three time points: the first 4-hour dark cycle, the second 4-hour dark cycle, and the whole light cycle. Both male and female mice displayed escalated alcohol intake after 3 weeks of chronic IA exposure, mainly occurring at the first 4-hour dark cycle (25\%-30\% in total daily intake), without much change in the other two time periods (Zhou et al., 2017a,c). Of interest, in both sexes the hypothalamic POMC-deficient mice displayed lower alcohol intake than the wild-type mice during the first 4-hour dark cycle (Zhou et al., 2017c), suggesting a potential contribution of hypothalamic POMC to the genetically determined tendency of hypothalamic POMC-deficient mice toward reduced alcohol consumption, with the potential influence of clock genes as found in other studies with alcohol (Spanagel et al., 2005; Agapito et al., 2010; Partonen, 2015).

$\beta$-Endorphin is critically involved in the regulation of HPA activity. In both animal and human studies, it has been demonstrated that endogenous $\beta$-endorphin has tonic inhibition of the HPA axis by acting on the MOP-r (e.g., Kreek and Koob, 1998; Wand et al., 2002; Zhou et al., 2017c). NTN is a clinical MOP-r antagonist in the treatment of alcoholism (O'Malley et al., 1992; Volpicelli et al., 1992). As $\beta$-endorphin exerts tonic inhibition of CRF in the PVN (central part of the HPA axis), NTN blocks MOP-r, disinhibits the inhibition of the CRF, and then acutely and persistently activates the HPA axis (O’Malley et al., 2002). In a human study, the NTNtreated group showed higher plasma ACTH and cortisol levels than the placebo-treated group. Of great interest, the alcoholcraving levels in both groups were negatively correlated with the plasma cortisol levels. As the first human laboratory study, the results clearly demonstrated that modest activation of the HPA axis by NTN contributed to either the suppression of alcohol craving or the reduction in alcohol drinking
(O'Malley et al., 2002). Other studies in humans support for this finding (e.g., Schuckit, 1994).

The potential role of endogenous ACTH and melanocortins in the brain (encoded by the Pomc gene) in the regulation of alcohol-related behavior is not clear. Recent pharmacologic studies have demonstrated that specific melanocortin 4 receptor (MC4) agonists significantly decrease alcohol binge-like drinking in a DID model as well as reduce appetitive and consumption behaviors (Olney et al., 2014; Sprow et al., 2016). In contrast, another study found that MC4 receptor antagonists in the ventral tegmental area reduced alcohol selfadministration in rats (Shelkar et al., 2015), suggesting that endogenous melanocortins and MC4 activation mediate the alcohol-reinforcing effect.

Endocannabinoid System. The endocannabinoid (eCB) system contains endogenous cannabinoids (including anandamide [AEA] and 2-arachidonoyl glycerol) and cannabinoid receptors ( $\mathrm{CB} 1$ and $\mathrm{CB} 2)$. In rodents, pharmacologic studies have demonstrated that specific blockade of $\mathrm{CB} 1$ receptors decreases alcohol drinking, blocks the motivation to consume alcohol, and reduces alcohol seeking, suggesting that the $\mathrm{eCB} / \mathrm{CB} 1$ system is important in mediating the positive reinforcing properties and consumption of alcohol (Arnone et al., 1997; Colombo et al., 1998; Gallate and McGregor, 1999; McGregor et al., 2005). Furthermore, CB1 knockout mice show reduced alcohol drinking or preference and alcohol reward (Hungund et al., 2003; Wang et al., 2003; Naassila et al., 2004; Houchi et al., 2005). Therefore, during early stages of alcohol drinking, increased eCB/CB1 activity may promote alcohol reward and then enhance alcohol intake (Manzanares et al., 1999).

After chronic alcohol exposure and protracted withdrawal, however, there may be an eCB/CB1 signaling deficiency, which could also increase alcohol intake via the negative reinforcement mechanism. This idea is supported by several findings. 1) In rats, down-regulation of CB1 expression and function was observed during protracted alcohol withdrawal (Mitrirattanakul et al., 2007; Varodayan et al., 2016). 2) In human imaging studies, decreased CB1 availability was observed in heavy-drinking alcoholics, which persisted into abstinence (Hirvonen et al., 2013; Ceccarini et al., 2014). 3) In alcohol-dependent human patients, a lowered plasma AEA level was found during recent abstinence (Mangieri et al., 2009).

AEA-dependent signaling is regulated by an enzyme involved in AEA catabolism: fatty acid amide hydrolase (FAAH) (Cravatt et al., 1996, 2001). Numerous studies have demonstrated that AEA is involved in the behavioral effects of alcohol. FAAH knockout mice show a resultant increase in AEA levels (Cravatt et al., 2001) and increased alcohol consumption and preference (Basavarajappa et al., 2006; Blednov et al., 2007) (Table 3). In human genetic studies, increased alcohol abuse and dependency are associated with the FAAH C385A polymorphism (increased eCB activity due to impaired FAAH function) (e.g., Sipe et al., 2002; Sloan et al., 2018) (Table 3). Consistently, we found increased alcohol consumption in knock-in mice with human FAAH C385A (Zhou et al., 2016), with reduced anxiety-like behavior (Dincheva et al., 2015).

Increased stress responsivity and persistent negative affective symptoms, such as anxiety and depression, are observed during alcohol withdrawal, and the severity may be associated with alcohol-relapse susceptibility (Koob and Kreek, 2007; 
TABLE 3

Effects of genetic mutation or deletion of FAAH gene and of FAAH inhibitors on alcohol-related behaviors

\begin{tabular}{|c|c|c|c|c|}
\hline Subjects & Sex & Model & Effect & Reference \\
\hline FAAH KO & $\begin{array}{l}\text { Male, } \\
\text { female }\end{array}$ & 2-Bottle choice $(24 \mathrm{~h}, 12 \%-20 \%)$ & $\begin{array}{l}\text { Increase (intake and preference), } \\
\text { with sex difference }\end{array}$ & $\begin{array}{l}\text { Basavarajappa } \\
\text { et al. (2006) }\end{array}$ \\
\hline FAAH KO & $\begin{array}{l}\text { Male, } \\
\text { female }\end{array}$ & $\begin{array}{l}\text { [1] 2-Bottle choice }(24 \mathrm{~h}, 3 \%-15 \%) \text {; } \\
\text { [2] CPP }\end{array}$ & $\begin{array}{l}\text { [1] Increase (intake and preference, } \\
\text { with sex difference; } \\
\text { [2] No effect }\end{array}$ & $\begin{array}{l}\text { Blednov et al. } \\
\quad(2007)\end{array}$ \\
\hline FAAH KO mice & $\begin{array}{l}\text { Male, } \\
\text { female }\end{array}$ & 2-Bottle choice ( $24 \mathrm{~h}, 3 \%-12 \%)$ & $\begin{array}{l}\text { Increase (intake and preference by } \\
\text { systemic (i.p.) URB597, } \\
\text { with sex difference }\end{array}$ & $\begin{array}{l}\text { Blednov et al. } \\
\quad(2007)\end{array}$ \\
\hline C57Bl/6J mice & $\begin{array}{l}\text { Male, } \\
\text { female }\end{array}$ & $\begin{array}{l}\text { [1] } 1 \text {-Bottle }(4 \mathrm{~h}, 15 \%) \text { in DID for } 3 \mathrm{wk} \text {; } \\
\text { [2] } 2 \text {-Bottle choice }(24 \mathrm{~h} \text {, every other day, } \\
7.5 \%-30 \%) \text { in IA; } \\
\text { [3] } \mathrm{ADE}\end{array}$ & $\begin{array}{l}\text { Decrease (intake and preference) by } \\
\text { systemic (i.p.) URB597 in IA and ADE } \\
\text { (but not DID) models, with no sex } \\
\text { difference }\end{array}$ & $\begin{array}{l}\text { Zhou et al. } \\
\text { (2017d) }\end{array}$ \\
\hline $\begin{array}{l}\text { Marchigian Sardinian } \\
\text { alcohol-preferring rats }\end{array}$ & Male & Operant self-administration $(10 \%, 30 \mathrm{~min})$ & $\begin{array}{l}\text { Decrease (intake) by intracentral and } \\
\text { basolateral amygdala URB597 }\end{array}$ & $\begin{array}{l}\text { Stopponi et al. } \\
\quad(2018)\end{array}$ \\
\hline FAAH C385A Knock-in mice & Male & $\begin{array}{l}\text { 1-Bottle ( } 4 \mathrm{~h}, 15 \%) \text { in DID for } 4 \text { days and } \\
2 \text {-bottle choice }(4 \mathrm{~h}, 15 \% \text { vs. water }) \text { on day } 5\end{array}$ & Increase (intake and preference) & $\begin{array}{l}\text { Zhou et al. } \\
\quad(2016)\end{array}$ \\
\hline Human FAAH C385A SNP & $\begin{array}{l}\text { Male, } \\
\text { female }\end{array}$ & 2119 Patients & $\begin{array}{l}\text { Association with street drug use and } \\
\text { problem drug/alcohol use }\end{array}$ & $\begin{array}{l}\text { Sipe } \\
\quad \text { et al. (2002) }\end{array}$ \\
\hline Human FAAH C385A SNP & $\begin{array}{l}\text { Male, } \\
\text { female }\end{array}$ & $\begin{array}{l}1434 \text { European Americans with } \mathrm{AD} \\
\text { diagnosis }\end{array}$ & $\begin{array}{l}\text { Association with probability } \\
\text { and severity of alcohol dependence }\end{array}$ & $\begin{array}{l}\text { Sloan et al. } \\
\text { (2018) }\end{array}$ \\
\hline
\end{tabular}

$\mathrm{AD}$, alcohol dependence; KO, knockout; SNP, single-nucleotide polymorphisms; URB597, FAAH inhibitor.

Koob and Volkow 2010). The eCBs have considerable modulatory effects on the extended amygdala and corticostriatal circuitries, and stress disrupts these eCB-enriched regions that are involved in emotional control (Serrano et al., 2012; Dincheva et al., 2015; Morena et al., 2016). Pharmacologic and genetic manipulations (knockout or knock-in) of FAAH are found to alter anxiety-like and depression-like behaviors (Kathuria et al., 2003; Bortolato et al., 2007; Moreira et al., 2008; Gunduz-Cinar et al., 2013; Carnevali et al., 2015). Therefore, increased anxiety and depression are associated with the relatively deficient $\mathrm{eCB}$ function. Thus, impaired eCB activity may contribute to the negative affective states and increased stress responsivity that underlie the negative reinforcement mechanisms driving alcohol drinking by dependent individuals, which may also contribute to alcohol relapse after abstinence (Parsons and Hurd, 2015).

Though FAAH inhibition had been found to decrease the anxiety-like behaviors that are present during alcohol withdrawal (Cippitelli et al., 2008), no studies had tested the effect of FAAH inhibitors on alcohol drinking during withdrawal. We hypothesized that FAAH inhibition would enhance eCB signaling and then reduce the negative effect of alcohol withdrawal, which might reduce excessive and relapse drinking. To explore its potential for its therapeutic agent for alcoholism, we have investigated whether URB597 ([3-(3carbamoylphenyl)phenyl] $N$-cyclohexylcarbamate), a selective FAAH inhibitor, alters alcohol drinking in mice during acute or chronic withdrawal from 3-week chronic IA excessive alcohol drinking (Zhou et al., 2017d). We also have investigated the pharmacologic effects of URB597 as a clinical FAAH inhibitor on the ADE. Mice were allowed to access to alcohol after 1 week of abstinence; after acute withdrawal from chronic IA, pretreatment with URB597 reduced alcohol intake and preference in both male and female mice. This effect was mediated through $\mathrm{CB} 1$ receptors. Of interest, the $\mathrm{ADE}$ can be prevented with an effective dose of URB597 via either a singleor multiple-dosing regimen, with no tolerance after 1 week of the multidosing regimen. At the most effective dose for reducing alcohol intake, URB597 had no effect on sucrose or saccharin preference in alcohol-naïve mice but increased the sucrose preference in mice after alcohol withdrawal (Zhou et al., 2017d).

In previous work, URB597 was found to increase the sucrose preference in stress-exposed animals, probably due to its "antidepression" properties (Bortolato et al., 2007; Rademacher and Hillard, 2007). Consistent with studies on cocaine, nicotine, and opioid seeking behavior (Panlilio et al., 2013; Sloan et al., 2017), our findings showed initial, promising data indicating that FAAH inhibitors decreases alcohol excessive drinking and relapse drinking in both male and female mice. Consistently, a new report has demonstrated that the CeA of alcohol-preferring rats is involved in the URB597 effect on reducing alcohol drinking (Stopponi et al., 2018) (Table 3).

Together, these results clearly suggest that the inhibition of FAAH plays a critical role in regulating alcohol drinking and related behaviors. Therefore, FAAH inhibitors with improved pharmacokinetics (long-lasting in vivo bioactivity, such as URB597) (Fegley et al., 2005; Basavarajappa et al., 2014) and with no rewarding effect (Gobbi et al., 2005) have the potential to become useful compounds for treating alcoholism (Zhou et al., 2017d; Stopponi et al., 2018).

$\kappa$ Opioid Receptor and Dynorphin System. Activation of the $\kappa$-opioid receptor (KOP-r)/dynorphin system is involved in aversive, dysphoria-like, and depression-like behaviors. For example, in dynorphin knockout mice, the aversive behaviors triggered by repeated forced swim or foot-shock stress are blocked by KOP-r antagonists or are absent (Land et al., 2008). Further study using an optogenetic approach has demonstrated that dynorphin/KOP-r in the NAc shell plays a functional role in aversive behaviors (Al-Hasani et al., 2015).

The dysphoric properties of chronic stress are encoded by dynorphin acting on KOP-r in specific stress-related brain regions, as dynorphin-dependent KOP-r activation by stress is found in these brain regions (including the basolateral amygdala, NAc, dorsal raphe, and hippocampus). Together, 
TABLE 4

Effects of KOP-r agonists or antagonists on alcohol-drinking behaviors

\begin{tabular}{|c|c|c|c|c|}
\hline Subjects & Sex & Model & Effect & Reference \\
\hline Wistar rats & Male & 4-Bottle choice (24 h, 5\%-20\%) & $\begin{array}{l}\text { Increase (intake and preference) by systemic } \\
\text { (minipump) enadoline; no change by systemic (i.p.) } \\
\text { nor-BNI }\end{array}$ & $\begin{array}{l}\text { Holter et al. } \\
\quad(2000)\end{array}$ \\
\hline Lewis rats & Male & 2-Bottle choice (24 h, 10\%) & Increase (intake) by systemic (s.c.) nor-BNI & $\begin{array}{l}\text { Mitchell et al. } \\
\quad(2005)\end{array}$ \\
\hline $\begin{array}{l}\mathrm{C} 57 \mathrm{Bl} / 6 \mathrm{~J} \\
\text { mice }\end{array}$ & Male & 2-Bottle choice ( $2 \mathrm{~h}, 10 \%-15 \%)$ & $\begin{array}{l}\text { Increase (intake and preference) by systemic (i.p.) } \\
\text { U50,488 }\end{array}$ & $\begin{array}{l}\text { Rose et al. } \\
\quad(2016)\end{array}$ \\
\hline $\begin{array}{l}\mathrm{C} 57 \mathrm{Bl} / 6 \mathrm{~J} \\
\text { mice }\end{array}$ & Male & 1-Bottle $(1 \mathrm{~h}, 15 \%)$ & $\begin{array}{l}\text { Increase (intake) by systemic (i.p.) U50,488; } \\
\text { decrease (intake) by systemic (i.p.) LY2444296 in } \\
\text { stressed mice }\end{array}$ & $\begin{array}{l}\text { Anderson } \\
\text { et al. } \\
\text { (2016) }\end{array}$ \\
\hline $\begin{array}{l}\mathrm{C} 57 \mathrm{Bl} / 6 \mathrm{~J} \\
\text { mice }\end{array}$ & $\begin{array}{l}\text { Male, } \\
\text { female }\end{array}$ & [1] 1-Bottle (4 h, 15\%) in DID for $3 \mathrm{wk}$; & $\begin{array}{l}\text { Decrease (intake and preference) by systemic (i.p.) } \\
\text { MSB in IA (but not DID) model, with no sex } \\
\text { difference }\end{array}$ & $\begin{array}{l}\text { Zhou et al. } \\
\quad(2017 a)\end{array}$ \\
\hline
\end{tabular}

Enadoline, k agonist; LY2444296, k antagonist; MSB, $\kappa$ agonist; nor-BNI, KOP-r antagonist; U50,488, KOP-r agonist [(trans)-3,4-dichloro-N-methyl-N-[2-(1-pyrrolidinyl)cyclohexyl]benzeneacetamide].

the dynorphin/KOP-r system is a key mediator of stressinduced aversion, dysphoria, and anxiety- and depression-like behaviors (Butelman et al., 2012; Lalanne et al., 2014).

Like stressors, KOP-r agonists stimulate HPA activity in rats, and the selective KOP-r antagonist nor-binaltorphimine (norBNI) blocks the stimulatory effects of KOP-r agonists on the HPA axis (e.g., Laorden and Milanes, 2000; Pascoe et al., 2008). Consistent with the early evidence that KOP-r/dynorphin regulates the HPA axis, our studies confirmed that blockade of KOP-r with nor-BNI prevents the ACTH and corticosterone increases that are induced by acute stress (Allen et al., 2013; Zhou et al., 2013c). In humans, KOP-r agonists or partial agonists increase plasma ACTH and cortisol levels (Ur et al., 1997; Schluger et al., 1998), and the short-acting KOP-r antagonist LY2456302 (4-[4-[[(2S)-2-(3,5-dimethylphenyl)pyrrolidin-1yl]methyl]phenoxy]-3-fluorobenzamide) does not cause aversive effects or HPA activity (Reed et al., 2018).

KOP-r/dynorphin activation is associated with the negative reinforcement aspects of alcohol addictions. It has been found that selective blockade of KOP-r attenuates excessive drinking and stress- or cue-induced alcohol-seeking in mice and rats (Walker and Koob, 2008; Sperling et al., 2010; Deehan et al., 2012; Schank et al., 2012; Funk et al., 2014; Rorick-Kehn et al., 2014; Anderson et al., 2016; Zhou et al., 2017a; but also see Mitchell et al., 2005; Sirohi et al., 2016). In line with these pharmacologic results, alcohol drinking is decreased in KOP-r knockout mice (Kovacs et al., 2005). These findings provide support for the critical involvement of the KOP-r/dynorphin system in the process of alcohol addiction, though the literature is not consistent (Table 4).

There are sex differences in dynorphin/KOP-r systems (Chartoff and Mavrikaki, 2015) and alcohol-drinking behavior (Becker and Koob, 2016). Indeed, we have observed a reduction of alcohol drinking with the selective KOP-r antagonist nor-BNI (slow onset and extraordinarily long-lasting effect; Horan et al., 1992) in male mice while the same norBNI treatment has had no effect on alcohol drinking in female mice (Zhou et al., 2017a).
Microdialysis studies have demonstrated that acute alcohol increases the extracellular levels of dynorphin A1-8 in the CeA and NAc, two brain regions known to play important roles in the regulation of alcohol consumption (Marinelli et al., 2006; Lam and Gianoulakis, 2011). Dynorphin mRNA levels in the CeA are increased in rats after acute alcohol withdrawal from multiple binge administrations of alcohol (D'Addario et al., 2013). The CeA is one of critical brain regions mediating depression-like and anxiety-like behaviors (Shippenberg et al., 2007; Knoll and Carlezon, 2010), and it is a possible site for the potential interaction of alcohol and the KOP$\mathrm{r} /$ dynorphin. In fact, in $\mathrm{sP}$ rats after a large amount of alcohol drinking, an increase in dynorphin mRNA levels is found in the CeA. Therefore, the KOP-r/dynorphin involved in neuronal structures related to stress responsivity (e.g., CeA) is activated after high levels of alcohol consumption in $\mathrm{sP}$ rats (Zhou et al., 2013a).

Chronic intermittent alcohol vapor exposure in alcoholdependent Wistar rats has further confirmed that there are increases in dynorphin peptide levels and KOP-r signaling in the CeA (Kissler et al., 2014). This enhanced KOP-r/dynorphin activity in the CeA may present a homeostatic adaptation of the CNS after chronic alcohol consumption or in the negative affective state during alcohol withdrawal. Further work has found that KOP-r activation inhibits both GABAergic synaptic responses and alcohol effects in the CeA (and BNST), and regulates GABA release (Li et al., 2012; Kang-Park et al., 2013). In the NAc shell, KOP-r blockade also reduces alcohol self-administration in alcohol-dependent rats (Nealey et al., 2011).

On the basis of these data, increased levels of KOPr/dynorphin in the CeA and NAc have been confirmed as playing a functional role in the regulation of the negative affective state and/or reward after alcohol exposure or withdrawal (Shippenberg et al., 2007; Wee and Koob, 2010).

Early work found that "classic" KOP-r agonists attenuated alcohol drinking and alcohol CPP (Lindholm et al., 2001; Logrip et al., 2009), but they also produced sedation and 
dysphoria-side effects that limited their potential for clinical use (e.g., Morani et al., 2009). The development of new KOP-r agonists with reduced side effects may produce useful compounds for the treatment of alcoholism. Rapidly growing research has focused on identifying functionally selective (biased) KOP-r full agonists or partial agonists for the development of antiaddictive compounds (Maillet et al., 2015; Simonson et al., 2015; White et al., 2015; Brust et al., 2016; Schattauer et al., 2017; Townsend et al., 2017; Zhou et al., 2017a).

For a good example, Mesyl Salvinorin B (MSB), an analog of salvinorin A, is a potent KOP-r full agonist with fewer side effects (sedation and dysphoria) compared with other classic KOP-r agonists (Simonson et al., 2015; Zhou et al., 2017a). We have further examined the pharmacologic effects of MSB on excessive or relapse drinking in mice to determine its potential for development as an antirelapse compound for alcoholism. Acute administration of MSB significantly reduced both excessive drinking in an IA model and relapse drinking in a mouse ADE model in a dose-dependent manner (Zhou et al., 2017a; 2018b). Nalfurafine, a clinically available G-biased KOP-r agonist (Schattauer et al., 2017), also decreases excessive alcohol drinking with few side effects in mice (Zhou and Kreek, 2018). These promising in vivo results indicate that biased KOP-r full agonists may offer novel approaches to treat alcoholism without the traditional dysphoric properties of classic KOP-r agonists.

Many studies have demonstrated that classic KOP-r agonists increase alcohol drinking (Rose et al., 2016) and induce alcohol-seeking behavior in a reinstatement model (Funk et al., 2014) and relapse drinking in a ADE model (Hölter et al., 2000; see an update review by Anderson and Becker, 2017). Therefore, our new data that the KOP-r full agonist MSB reduces, rather than triggers, relapse-like drinking present an opposite scenario. After chronic excessive alcohol consumption, the endogenous dynorphin (a G-protein- and $\beta$-arrestin-dependent agonist; Maillet et al., 2015; White et al., 2015) and KOP-r systems are activated in several neuronal structures. Either the increased release of dynorphin (Marinelli et al., 2006) or the enhanced KOP-r activity (Rose et al., 2016) produces sedation, dysphoria, and anxiety- and depression-like behaviors that may drive excessive and relapse drinking (Tunstall et al., 2017). In support of this concept, the dynorphin levels and KOP-r activity are found to be increased in the rat CeA after chronic alcohol exposure (D'Addario et al., 2013; Zhou et al., 2013a; Kissler et al., 2014). Indeed, preclinical studies have demonstrated that the activation of p38 mitogen-activated protein kinase to stressmediated dynorphin/KOP-r stimulation is linked to the $\beta$-arrestin-mediated transduction pathway (Bruchas et al., 2007, 2010). Unlike dynorphin, however, MSB does not induce sedation or anhedonia in rats or mice (Simonson et al., 2015; Zhou et al., 2017a), and could act as a G-protein-dependent (biased) agonist, which was suggested by our recent report (Simonson et al., 2015). Nalfurafine, acting as a biased KOP-r agonist, could possibly compete with excessive dynorphin to bind the KOP-r, thereby reducing $\beta$-arrestin signaling. This could be responsible, at least in part, for reducing excessive alcohol intake, as nalfurafine reverses the dynorphinenhanced dysphoria and anxiety- or depression-like behavior during alcohol withdrawal.

Together, these studies support the notion that biased KOP-r agonists exhibit different molecular, cellular, and behavioral properties than classic KOP-r agonists (Che et al., 2018). Our study is in line with the growing research into the development of biased KOP-r ligands for antiaddictive compounds (Maillet et al., 2015; White et al., 2015; Brust et al., 2016; Townsend et al., 2017).

\section{Conclusion and Future Directions}

As presented in this mini-review, substantial progress has been made in our understanding how alcohol exposure disrupts the CNS stress-responsive systems to modulate alcohol taking and seeking behaviors in several selective animal models. It has been well known that the MOP-r/POMC and KOP-r/dynorphin endogenous opioid systems play critical roles in alcohol addiction, and specific alterations of their expression levels or receptor activity may affect stress responsivity and contribute to vulnerability to developing alcohol dependency or relapse. Other stress-responsive systems discussed here (including the V1b receptor with AVP, and FAAH with eCBs) are also potentially involved in alcohol addiction, as new evidence has emerged in recent studies.

Combination medications targeting multiple neurotransmitter pathways may show increased efficacy over the traditional single-medication strategy. As discussed previously, pharmacologic and neurobiologic studies have provided strong supportive findings; many stress-responsive systems, including $\mathrm{CRF}$, neuropeptide $\mathrm{Y}$, and glucocorticoid receptor, are profoundly disrupted after chronic alcohol exposure. Further studies on combination medications are needed to develop more effective new pharmacotherapies for treating alcoholism.

Although NTN is more effective in individuals with alcoholism who have MOP-r variant A118G (Bond et al., 1998; Bart et al., 2004; Kreek and LaForge, 2007; Anton et al., 2008), the single-target pharmacotherapy has relatively modest therapeutic value, which suggests the need for better efficacy (Müller et al., 2014). By targeting multiple neurotransmitters implicated in different components of alcohol addiction, combination medications are expected to have greater efficacy than single-medication therapy (Karoly et al., 2015; Zhou and Leri, 2016). Combinations of NTN with other compounds have several precedent in rodent models, such as acamprosate (Heyser et al., 2003) and prazosin (Froehlich et al., 2013).

Consistently, our recent studies in mouse alcohol-escalation drinking models have suggested that the combination of KOP-r agonist MSB, V1b antagonist SSR149415, or bupropion with NTN may be more efficacious in treating alcoholism than NTN alone (Zhou et al., 2017a, 2018a). 1) The effect of combined, lowdose administration of MSB/NTN, SSR149415/NTN, or bupropion/NTN on alcohol drinking is greater than that of either drug alone. 2) The combinations show persistent effects after repeated administration. In support of this idea, the effective medication nalmefene is a MOP-r antagonist plus a KOP-r partial agonist (Bart et al, 2005), targeting both MOP-r and KOP-r pathways and possibly synergistically reducing alcohol consumption.

Indeed, most drugs tested for alcoholism treatmenttopiramate, varenicline, and gabapentin-target multiple systems (Karoly et al., 2015). Multiple targeting may have great advantages for treating alcoholism as a multigenic disease. Therefore, we propose that the combination drugs may prove more effective than drugs that are highly selective for a single target. 


\section{Acknowledgments}

The authors thank the late Dr. Robert A. Schaefer and Michelle Morochnik for providing their editing corrections on the manuscript.

\section{Authorship Contributions}

Wrote or contributed to the writing of the manuscript: Zhou, Kreek.

\section{References}

Adinoff B, Martin PR, Bone GHA, Eckardt M, Roehrich L, George DT, Moss HB, Eskay R, Linnoila M, and Gold PW (1990) Hypothalamic-pituitary-adrenal axis functioning and cerebrospinal fluid corticotropin levels in alcoholics after recent and long-term abstinence. Arch Gen Psychiatry 47:325-330.

Agapito M, Mian N, Boyadjieva NI, and Sarkar DK (2010) Period 2 gene deletion abolishes beta-endorphin neuronal response to ethanol. Alcohol Clin Exp Res 34 1613-1618.

Aguilera G and Rabadan-Diehl C (2000) Vasopressinergic regulation of the hypothalamic-pituitary-adrenal axis: implications for stress adaptation. Regul Pept 96:23-29.

Al-Hasani R, McCall JG, Shin G, Gomez AM, Schmitz GP, Bernardi JM, Pyo CO, Park SI, Marcinkiewcz CM, Crowley NA, et al. (2015) Distinct subpopulations of nucleus accumbens dynorphin neurons drive aversion and reward. Neuron 87: 1063-1077.

Allen CP, Zhou Y, and Leri F (2013) Effect of food restriction on cocaine locomotor sensitization in Sprague-Dawley rats: role of kappa opioid receptors. Psychopharmacology (Berl) 226:571-578.

Amalric M, Cline EJ, Martinez JL, Jr, Bloom FE, and Koob GF (1987) Rewarding properties of beta-endorphin as measured by conditioned place preference. Psychopharmacology (Berl) 91:14-19.

Anderson RI and Becker HC (2017) Role of the dynorphin/kappa opioid receptor system in the motivational effects of ethanol. Alcohol Clin Exp Res 41:1402-1418.

Anderson RI, Lopez MF, and Becker HC (2016) Stress-Induced enhancement of ethanol intake in C57BL/6J mice with a history of chronic ethanol exposure: involvement of kappa opioid receptors. Front Cell Neurosci 10:45.

Angelogianni P and Gianoulakis C (1993) Chronic ethanol increases proopiomelanocortin gene expression in the rat hypothalamus. Neuroendocrinology 57:106-114.

Anton RF, Oroszi G, O'Malley S, Couper D, Swift R, Pettinati H, and Goldman D (2008) An evaluation of mu-opioid receptor (OPRM1) as a predictor of naltrexone response in the treatment of alcohol dependence: results from the Combined Pharmacotherapies and Behavioral Interventions for Alcohol Dependence (COMBINE) study. Arch Gen Psychiatry 65:135-144

Arnone M, Maruani J, Chaperon F, Thiébot MH, Poncelet M, Soubrié P, and Le Fur G (1997) Selective inhibition of sucrose and ethanol intake by SR 141716, an antagonist of central cannabinoid (CB1) receptors. Psychopharmacology (Berl) 132:104-106.

Barson JR, Morganstern I, and Leibowitz SF (2011) Similarities in hypothalamic and mesocorticolimbic circuits regulating the overconsumption of food and alcohol. Physiol Behav 104:128-137.

Bart G, Heilig M, LaForge KS, Pollak L, Leal SM, Ott J, and Kreek MJ (2004) Substantial attributable risk related to a functional mu-opioid receptor gene polymorphism in association with heroin addiction in central Sweden. Mol Psychiatry 9:547-549.

Bart G, Schluger JH, Borg L, Ho A, Bidlack JM, and Kreek MJ (2005) Nalmefene induced elevation in serum prolactin in normal human volunteers: partial kappa opioid agonist activity? Neuropsychopharmacology 30:2254-2262.

Basavarajappa BS, Nagre NN, Xie S, and Subbanna S (2014) Elevation of endogenous anandamide impairs LTP, learning, and memory through CB1 receptor signaling in mice. Hippocampus 24:808-818.

Basavarajappa BS, Yalamanchili R, Cravatt BF, Cooper TB, and Hungund BL (2006) Increased ethanol consumption and preference and decreased ethanol sensitivity in female FAAH knockout mice. Neuropharmacology 50:834-844.

Becker JB and Koob GF (2016) Sex differences in animal models: focus on addiction. Pharmacol Rev 68:242-263.

Bell RL, Sable HJK, Colombo G, Hyytiä P, Rodd ZA, and Lumeng L (2012) Animal models for medications development targeting alcohol abuse using selectively bred rat lines: neurobiological and pharmacological validity. Pharmacol Biochem Behav 103:119-155

Ben Hamida S, Boulos LJ, McNicholas M, Charbogne P, and Kieffer BL (2017) Mu opioid receptors in GABAergic neurons of the forebrain promote alcohol reward and drinking. Addict Biol [published ahead of print].

Blaine SK and Sinha R (2017) Alcohol, stress, and glucocorticoids: from risk to dependence and relapse in alcohol use disorders. Neuropharmacology 122:136-147.

Blednov YA, Cravatt BF, Boehm SL, II, Walker D, and Harris RA (2007) Role of endocannabinoids in alcohol consumption and intoxication: studies of mice lacking fatty acid amide hydrolase. Neuropsychopharmacology 32:1570-1582.

Bodnar RJ (2014) Endogenous opiates and behavior: 2013. Peptides 62:67-136.

Bond C, LaForge KS, Tian M, Melia D, Zhang S, Borg L, Gong J, Schluger J, Strong JA, Leal SM, et al. (1998) Single-nucleotide polymorphism in the human mu opioid receptor gene alters beta-endorphin binding and activity: possible implications for opiate addiction. Proc Natl Acad Sci USA 95:9608-9613.

Bortolato M, Mangieri RA, Fu J, Kim JH, Arguello O, Duranti A, Tontini A, Mor M, Tarzia G, and Piomelli D (2007) Antidepressant-like activity of the fatty acid amide hydrolase inhibitor URB597 in a rat model of chronic mild stress. Biol Psychiatry 62:1103-1110.

Brown DR and Holtzman SG (1981) Suppression of drinking by naloxone in the rat: a further characterization. Eur J Pharmacol 69:331-340.

Bruchas MR, Land BB, Aita M, Xu M, Barot SK, Li S, and Chavkin C (2007) Stressinduced p38 mitogen-activated protein kinase activation mediates kappa-opioiddependent dysphoria. J Neurosci 27:11614-11623.
Bruchas MR, Land BB, and Chavkin C (2010) The dynorphin/kappa opioid system as a modulator of stress-induced and pro-addictive behaviors. Brain Res 1314: $44-55$.

Brust TF, Morgenweck J, Kim SA, Rose JH, Locke JL, Schmid CL, Zhou L, Stahl EL, Cameron MD, Scarry SM, et al. (2016) Biased agonists of the kappa opioid receptor suppress pain and itch without causing sedation or dysphoria. $S c i$ Signal 9:ra117.

Bumaschny VF, Yamashita M, Casas-Cordero R, Otero-Corchón V, de Souza FS, Rubinstein M, and Low MJ (2012) Obesity-programmed mice are rescued by early genetic intervention. $J$ Clin Invest 122:4203-4212.

Butelman ER, Yuferov V, and Kreek MJ (2012) $\kappa$-Opioid receptor/dynorphin system: genetic and pharmacotherapeutic implications for addiction. Trends Neurosci $\mathbf{3 5}$ : $587-596$

Carnevali L, Vacondio F, Rossi S, Callegari S, Macchi E, Spadoni G, Bedini A, Rivara S, Mor M, and Sgoifo A (2015) Antidepressant-like activity and cardioprotective effects of fatty acid amide hydrolase inhibitor URB694 in socially stressed Wistar Kyoto rats. Eur Neuropsychopharmacol 25:2157-2169.

Ceccarini J, Hompes T, Verhaeghen A, Casteels C, Peuskens H, Bormans G, Claes $\mathrm{S}$, and Van Laere K (2014) Changes in cerebral CB1 receptor availability after acute and chronic alcohol abuse and monitored abstinence. $J$ Neurosci 34: $2822-2831$

Chartoff EH and Mavrikaki M (2015) Sex differences in kappa opioid receptor function and their potential impact on addiction. Front Neurosci 9:466.

Chavkin C and Koob GF (2016) Dynorphin, dysphoria, and dependence: the stress of addiction. Neuropsychopharmacology 41:373-374.

Che T, Majumdar S, Zaidi SA, Ondachi P, McCorvy JD, Wang S, Mosier PD, Uprety R, Vardy E, Krumm BE, et al. (2018) Structure of the nanobody-stabilized active state of the kappa opioid receptor. Cell 172:55-67.e15.

Cippitelli A, Cannella N, Braconi S, Duranti A, Tontini A, Bilbao A, Defonseca FR, Piomelli D, and Ciccocioppo R (2008) Increase of brain endocannabinoid anandamide levels by FAAH inhibition and alcohol abuse behaviours in the rat. Psychopharmacology (Berl) 198:449-460.

Civelli O, Birnberg N, and Herbert E (1982) Detection and quantitation of proopiomelanocortin mRNA in pituitary and brain tissues from different species. $J$ Biol Chem 257:6783-6787.

Colombo G, Agabio R, Fà M, Guano L, Lobina C, Loche A, Reali R, and Gessa GL (1998) Reduction of voluntary ethanol intake in ethanol-preferring sP rats by the cannabinoid antagonist SR-141716. Alcohol Alcohol 33:126-130.

Colombo G, Lobina C, Carai MAM, and Gessa GL (2006) Phenotypic characterization of genetically selected Sardinian alcohol-preferring (sP) and -non-preferring (sNP) rats. Addict Biol 11:324-338.

Cowley MA, Smart JL, Rubinstein M, Cerdán MG, Diano S, Horvath TL, Cone RD, and Low MJ (2001) Leptin activates anorexigenic POMC neurons through a neural network in the arcuate nucleus. Nature 411:480-484.

Cravatt BF, Demarest K, Patricelli MP, Bracey MH, Giang DK, Martin BR, and Lichtman AH (2001) Supersensitivity to anandamide and enhanced endogenous cannabinoid signaling in mice lacking fatty acid amide hydrolase. Proc Natl Acad Sci USA 98:9371-9376.

Cravatt BF, Giang DK, Mayfield SP, Boger DL, Lerner RA, and Gilula NB (1996) Molecular characterization of an enzyme that degrades neuromodulatory fatty-acid amides. Nature 384:83-87.

D'Addario C, Caputi FF, Rimondini R, Gandolfi O, Del Borrello E, Candeletti S, and Romualdi P (2013) Different alcohol exposures induce selective alterations on the expression of dynorphin and nociceptin systems related genes in rat brain. Addict Biol 18:425-433.

Deehan GA, Jr, McKinzie DL, Carroll FI, McBride WJ, and Rodd ZA (2012) The longlasting effects of JDTic, a kappa opioid receptor antagonist, on the expression of ethanol-seeking behavior and the relapse drinking of female alcohol-preferring $(P)$ rats. Pharmacol Biochem Behav 101:581-587.

Dincheva I, Drysdale AT, Hartley CA, Johnson DC, Jing D, King EC, Ra S, Gray JM Yang R, DeGruccio AM, et al. (2015) FAAH genetic variation enhances frontoamygdala function in mouse and human. Nat Commun 6:6395-6404.

Edwards S, Guerrero M, Ghoneim OM, Roberts E, and Koob GF (2012) Evidence that vasopressin $\mathrm{V} 1 \mathrm{~b}$ receptors mediate the transition to excessive drinking in ethanoldependent rats. Addict Biol 17:76-85.

Eisenhofer G, Lambie DG, Whiteside EA, and Johnson RH (1985) Vasopressin concentrations during alcohol withdrawal. $\mathrm{Br}$ J Addict 80:195-199.

Fegley D, Gaetani S, Duranti A, Tontini A, Mor M, Tarzia G, and Piomelli D (2005) Characterization of the fatty acid amide hydrolase inhibitor cyclohexyl carbamic acid 3'-carbamoyl-biphenyl-3-yl ester (URB597): effects on anandamide and oleoylethanolamide deactivation. J Pharmacol Exp Ther 313:352-358.

Froehlich JC, Hausauer BJ, and Rasmussen DD (2013) Combining naltrexone and prazosin in a single oral medication decreases alcohol drinking more effectively than does either drug alone. Alcohol Clin Exp Res 37:1763-1770.

Funk D, Coen K, and Lê AD (2014) The role of kappa opioid receptors in stressinduced reinstatement of alcohol seeking in rats. Brain Behav 4:356-367.

Gallate JE and McGregor IS (1999) The motivation for beer in rats: effects of ritanserin, naloxone and SR 141716. Psychopharmacology (Berl) 142:302-308.

Gianoulakis C (1993) Endogenous opioids and excessive alcohol consumption. $J$ Psychiatry Neurosci 18:148-156.

Gianoulakis C, Hutchison WD, and Kalant H (1988) Effects of ethanol treatment and withdrawal on biosynthesis and processing of proopiomelanocortin by the rat neurointermediate lobe. Endocrinology 122:817-825.

Gobbi G, Bambico FR, Mangieri R, Bortolato M, Campolongo P, Solinas M, Cassano T, Morgese MG, Debonnel G, Duranti A, et al. (2005) Antidepressant-like activity and modulation of brain monoaminergic transmission by blockade of anandamide hydrolysis. Proc Natl Acad Sci USA 102:18620-18625.

Goutier W, Kloeze M, and McCreary AC (2016) Nicotine-induced locomotor sensitization: pharmacological analyses with candidate smoking cessation aids. Addict Biol 21:234-241. 
Grahame NJ, Mosemiller AK, Low MJ, and Froehlich JC (2000) Naltrexone and alcohol drinking in mice lacking beta-endorphin by site-directed mutagenesis. Pharmacol Biochem Behav 67:759-766.

Granholm L, Todkar A, Bergman S, Nilsson K, Comasco E, and Nylander I (2017) The expression of opioid genes in non-classical reward areas depends on early life conditions and ethanol intake. Brain Res 1668:36-45.

Griebel G, Simiand J, Serradeil-Le Gal C, Wagnon J, Pascal M, Scatton B, Maffrand JP and Soubrie P (2002) Anxiolytic- and antidepressant-like effects of the non-peptide vasopressin V1b receptor antagonist, SSR149415, suggest an innovative approach for the treatment of stress-related disorders. Proc Natl Acad Sci USA 99 $6370-6375$.

Grisel JE, Mogil JS, Grahame NJ, Rubinstein M, Belknap JK, Crabbe JC, and Low MJ (1999) Ethanol oral self-administration is increased in mutant mice with decreased beta-endorphin expression. Brain Res 835:62-67.

Gulya K, Dave JR, and Hoffman PL (1991) Chronic ethanol ingestion decreases vasopressin mRNA in hypothalamic and extrahypothalamic nuclei of mouse brain Brain Res 557:129-135.

Gunduz-Cinar O, MacPherson KP, Cinar R, Gamble-George J, Sugden K, Williams B, Godlewski G, Ramikie TS, Gorka AX, Alapafuja SO, et al. (2013) Convergent translational evidence of a role for anandamide in amygdala-mediated fear extinction, threat processing and stress-reactivity. Mol Psychiatry 18:813-823.

Hall FS, Sora I, and Uhl GR (2001) Ethanol consumption and reward are decreased in mu-opiate receptor knockout mice. Psychopharmacology (Berl) 154:43-49.

Harding AJ, Halliday GM, Ng JL, Harper CG, and Kril JJ (1996) Loss of vasopressinimmunoreactive neurons in alcoholics is dose-related and time-dependent. $\mathrm{Neu}$ roscience 72:699-708.

Hernando F, Schoots O, Lolait SJ, and Burbach JP (2001) Immunohistochemical localization of the vasopressin $\mathrm{V} 1 \mathrm{~b}$ receptor in the rat brain and pituitary gland: anatomical support for its involvement in the central effects of vasopressin. Endocrinology 142:1659-1668.

Herz A (1997) Endogenous opioid systems and alcohol addiction. Psychopharmacology (Berl) 129:99-111.

Heyser CJ, Moc K, and Koob GF (2003) Effects of naltrexone alone and in combination with acamprosate on the alcohol deprivation effect in rats. Neuropsychopharmacology 28:1463-1471.

Hirvonen J, Zanotti-Fregonara P, Umhau JC, George DT, Rallis-Frutos D, Lyoo CH, Li CT, Hines CS, Sun H, Terry GE, et al. (2013) Reduced cannabinoid CB1 receptor binding in alcohol dependence measured with positron emission tomography. Mol Psychiatry 18:916-921.

Hoffman PL and Dave JR (1991) Chronic ethanol exposure uncouples vasopressin synthesis and secretion in rats. Neuropharmacology 30:1245-1249.

Hölter SM, Henniger MS, Lipkowski AW, and Spanagel R (2000) Kappa-opioid receptors and relapse-like drinking in long-term ethanol-experienced rats. Psychopharmacology (Berl) 153:93-102.

Hölter SM and Spanagel R (1999) Effects of opiate antagonist treatment on the alcohol deprivation effect in long-term ethanol-experienced rats. Psychopharmacology (Berl) 145:360-369.

Horan P, Taylor J, Yamamura HI, and Porreca F (1992) Extremely long-lasting antagonistic actions of nor-binaltorphimine (nor-BNI) in the mouse tail-flick test. $J$ Pharmacol Exp Ther 260:1237-1243.

Houchi H, Babovic D, Pierrefiche O, Ledent C, Daoust M, and Naassila M (2005) CB1 receptor knockout mice display reduced ethanol-induced conditioned place preference and increased striatal dopamine D2 receptors. Neuropsychopharmacology 30:339-349.

Hundt W, Zimmermann U, Pöttig M, Spring K, and Holsboer F (2001) The combined dexamethasone-suppression/CRH-stimulation test in alcoholics during and after acute withdrawal. Alcohol Clin Exp Res 25:687-691.

Hungund BL, Szakall I, Adam A, Basavarajappa BS, and Vadasz C (2003) Cannabinoid $\mathrm{CB} 1$ receptor knockout mice exhibit markedly reduced voluntary alcohol consumption and lack alcohol-induced dopamine release in the nucleus accumbens. $J$ Neurochem 84:698-704.

Hwa LS, Chu A, Levinson SA, Kayyali TM, DeBold JF, and Miczek KA (2011) Persistent escalation of alcohol drinking in C57BL/6J mice with intermittent access to 20\% ethanol. Alcohol Clin Exp Res 35:1938-1947.

Hwang BH, Froehlich JC, Hwang WS, Lumeng L, and Li T-K (1998) More vasopressin mRNA in the paraventricular hypothalamic nucleus of alcohol-preferring rats and high alcohol-drinking rats selectively bred for high alcohol preference. Alcohol Clin Exp Res 22:664-669.

Imperio CG, McFalls AJ, Colechio EM, Masser DR, Vrana KE, Grigson PS, and Freeman WM (2016) Assessment of individual differences in the rat nucleus accumbens transcriptome following taste-heroin extended access. Brain Res Bull 123:71-80.

Inder WJ, Joyce PR, Ellis MJ, Evans MJ, Livesey JH, and Donald RA (1995) The effects of alcoholism on the hypothalamic-pituitary-adrenal axis: interaction with endogenous opioid peptides. Clin Endocrinol (Oxf) 43:283-290.

Ishizawa H, Dave JR, Liu LI, Tabakoff B, and Hoffman PL (1990) Hypothalamic vasopressin mRNA levels in mice are decreased after chronic ethanol ingestion. Eur J Pharmacol 189:119-127.

Jamensky NT and Gianoulakis C (1999) Comparison of the proopiomelanocortin and proenkephalin opioid peptide systems in brain regions of the alcohol-preferring C57BL/6 and alcohol-avoiding DBA/2 mice. Alcohol 18:177-187.

Kang-Park M, Kieffer BL, Roberts AJ, Siggins GR, and Moore SD (2013) $\kappa$-Opioid receptors in the central amygdala regulate ethanol actions at presynaptic GABAergic sites. $J$ Pharmacol Exp Ther 346:130-137.

Karkhanis A, Holleran KM, and Jones SR (2017) Dynorphin/kappa opioid receptor signaling in preclinical models of alcohol, drug, and food addiction. Int Rev Neurobiol 136:53-88.

Karoly HC, YorkWilliams SL, and Hutchison KE (2015) Clinical neuroscience of addiction: similarities and differences between alcohol and other drugs. Alcoho Clin Exp Res 39:2073-2084.
Kathuria S, Gaetani S, Fegley D, Valiño F, Duranti A, Tontini A, Mor M, Tarzia G, La Rana G, Calignano A, et al. (2003) Modulation of anxiety through blockade of anandamide hydrolysis. Nat Med 9:76-81.

Katz DA, Locke C, Liu W, Zhang J, Achari R, Wesnes KA, and Tracy KA (2016) Single-dose interaction study of the arginine vasopressin type $1 \mathrm{~B}$ receptor antagonist ABT-436 and alcohol in moderate alcohol drinkers. Alcohol Clin Exp Res 40: 838-845.

Kissler JL, Sirohi S, Reis DJ, Jansen HT, Quock RM, Smith DG, and Walker BM (2014) The one-two punch of alcoholism: role of central amygdala dynorphins/kappa-opioid receptors. Biol Psychiatry 75:774-782.

Knoll AT and Carlezon WA, Jr (2010) Dynorphin, stress, and depression. Brain Res 1314:56-73.

Koch M, Varela L, Kim JG, Kim JD, Hernández-Nuño F, Simonds SE, Castorena CM, Vianna CR, Elmquist JK, Morozov YM, et al. (2015) Hypothalamic POMC neurons promote cannabinoid-induced feeding. Nature 519:45-50.

Koob G and Kreek MJ (2007) Stress, dysregulation of drug reward pathways, and the transition to drug dependence. Am J Psychiatry 164:1149-1159.

Koob GF and Mason BJ (2016) Existing and future drugs for the treatment of the dark side of addiction. Annu Rev Pharmacol Toxicol 56:299-322.

Koob GF and Volkow ND (2010) Neurocircuitry of addiction. Neuropsychopharmacology 35:217-238.

Kornet M, Goosen C, Ribbens LG, and Van Ree JM (1991) The effect of desglycinamide-(Arg8)-vasopressin (DGAVP) on the acquisition of free-choice alcohol drinking in rhesus monkeys. Alcohol Clin Exp Res 15:72-79.

Kovacs KM, Szakall I, O'Brien D, Wang R, Vinod KY, Saito M, Simonin F, Kieffer BL, and Vadasz C (2005) Decreased oral self-administration of alcohol in kappa-opioid receptor knock-out mice. Alcohol Clin Exp Res 29:730-738.

Kreek MJ and Koob GF (1998) Drug dependence: stress and dysregulation of brain reward pathways. Drug Alcohol Depend 51:23-47.

Kreek MJ and LaForge KS (2007) Stress responsivity, addiction, and a functional variant of the human mu-opioid receptor gene. Mol Interv 7:74-78.

Kuzmin A, Sandin J, Terenius L, and Ogren SO (2003) Acquisition, expression, and reinstatement of ethanol-induced conditioned place preference in mice: effects of opioid receptor-like 1 receptor agonists and naloxone. J Pharmacol Exp Ther 304: 310-318.

Lalanne L, Ayranci G, Kieffer BL, and Lutz PE (2014) The kappa opioid receptor: from addiction to depression, and back. Front Psychiatry 5:170.

Lam DD, de Souza FSJ, Nasif S, Yamashita M, López-Leal R, Otero-Corchon V, Meece K, Sampath H, Mercer AJ, Wardlaw SL, et al. (2015) Partially redundant enhancers cooperatively maintain Mammalian pomc expression above a critical functional threshold. PLoS Genet 11:e1004935.

Lam MP and Gianoulakis C (2011) Effects of corticotropin-releasing hormone receptor antagonists on the ethanol-induced increase of dynorphin A1-8 release in the rat central amygdala. Alcohol 45:621-630.

Land BB, Bruchas MR, Lemos JC, Xu M, Melief EJ, and Chavkin C (2008) The dysphoric component of stress is encoded by activation of the dynorphin kappaopioid system. J Neurosci 28:407-414.

Laorden ML and Milanés MV (2000) Effects of U-50,488H and U-50,488H withdrawal on catecholaminergic neurons of the rat hypothalamus. Life Sci 66 : $803-815$.

Lee S and Rivier C (1997) An initial, three-day-long treatment with alcohol induces a long-lasting phenomenon of selective tolerance in the activity of the rat hypothalamic-pituitary-adrenal axis. J Neurosci 17:8856-8866.

Le Merrer J, Becker JA, Befort K, and Kieffer BL (2009) Reward processing by the opioid system in the brain. Physiol Rev 89:1379-1412.

Leriche M, Cote-Vélez A, and Méndez M (2007) Presence of pro-opiomelanocortin mRNA in the rat medial prefrontal cortex, nucleus accumbens and ventral tegmental area: studies by RT-PCR and in situ hybridization techniques. Neuropeptides 41:421-431.

Li C, Pleil KE, Stamatakis AM, Busan S, Vong L, Lowell BB, Stuber GD, and Kash TL (2012) Presynaptic inhibition of gamma-aminobutyric acid release in the bed nucleus of the stria terminalis by kappa opioid receptor signaling. Biol Psychiatry 71:725-732.

Lindholm S, Werme M, Brené S, and Franck J (2001) The selective kappa-opioid receptor agonist U50,488H attenuates voluntary ethanol intake in the rat. Behav Brain Res 120:137-146.

Liu X and Weiss F (2002) Additive effect of stress and drug cues on reinstatement of ethanol seeking: exacerbation by history of dependence and role of concurrent activation of corticotropin-releasing factor and opioid mechanisms. $J$ Neurosci 22 $7856-7861$

Logrip ML, Janak PH, and Ron D (2009) Blockade of ethanol reward by the kappa opioid receptor agonist U50,488H. Alcohol 43:359-365.

Lolait SJ, O'Carroll AM, Mahan LC, Felder CC, Button DC, Young WS, III, Mezey E, and Brownstein MJ (1995) Extrapituitary expression of the rat V1b vasopressin receptor gene. Proc Natl Acad Sci USA 92:6783-6787.

Lukas SE, Lowen SB, Lindsey KP, Conn N, Tartarini W, Rodolico J, Mallya G, Palmer C, and Penetar DM (2013) Extended-release naltrexone (XR-NTX) attenuates brain responses to alcohol cues in alcohol-dependent volunteers: a bold FMRI study. Neuroimage 78:176-185.

Maillet EL, Milon N, Heghinian MD, Fishback J, Schürer SC, Garamszegi N, and Mash DC (2015) Noribogaine is a G-protein biased к-opioid receptor agonist. Neuropharmacology 99:675-688.

Mangieri RA, Hong KI, Piomelli D, and Sinha R (2009) An endocannabinoid signal associated with desire for alcohol is suppressed in recently abstinent alcoholics. Psychopharmacology (Berl) 205:63-72.

Mantsch JR, Baker DA, Funk D, Lê AD, and Shaham Y (2016) Stress-induced reinstatement of drug seeking: 20 years of progress. Neuropsychopharmacology 41:335-356.

Manzanares J, Corchero J, Romero J, Fernández-Ruiz JJ, Ramos JA, and Fuentes JA (1999) Pharmacological and biochemical interactions between opioids and cannabinoids. Trends Pharmacol Sci 20:287-294. 
Marinelli PW, Lam M, Bai L, Quirion R, and Gianoulakis C (2006) A microdialysis profile of dynorphin $\mathrm{A}(1-8)$ release in the rat nucleus accumbens following alcohol administration. Alcohol Clin Exp Res 30:982-990.

Marinelli PW, Quirion R, and Gianoulakis C (2003) A microdialysis profile of betaendorphin and catecholamines in the rat nucleus accumbens following alcohol administration. Psychopharmacology (Berl) 169:60-67.

Mason BJ (2017) Emerging pharmacotherapies for alcohol use disorder. Neuropharmacology 122:244-253.

McGregor IS, Dam KD, Mallet PE, and Gallate JE (2005) 49 -THC reinstates beerand sucrose-seeking behaviour in abstinent rats: comparison with midazolam, food deprivation and predator odour. Alcohol Alcohol 40:35-45.

Mercer AJ, Hentges ST, Meshul CK, and Low MJ (2013) Unraveling the central proopiomelanocortin neural circuits. Front Neurosci 7:19-25.

Mitchell JM, Liang MT, and Fields HL (2005) A single injection of the kappa opioid antagonist norbinaltorphimine increases ethanol consumption in rats. Psychopharmacology (Berl) 182:384-392.

Mitrirattanakul S, López-Valdés HE, Liang J, Matsuka Y, Mackie K, Faull KF, and Spigelman I (2007) Bidirectional alterations of hippocampal cannabinoid 1 receptors and their endogenous ligands in a rat model of alcohol withdrawal and dependence. Alcohol Clin Exp Res 31:855-867.

Morani AS, Kivell B, Prisinzano TE, and Schenk S (2009) Effect of kappa-opioid receptor agonists U69593, U50488H, spiradoline and salvinorin A on cocaineinduced drug-seeking in rats. Pharmacol Biochem Behav 94:244-249.

Moreira FA, Kaiser N, Monory K, and Lutz B (2008) Reduced anxiety-like behaviour induced by genetic and pharmacological inhibition of the endocannabinoiddegrading enzyme fatty acid amide hydrolase (FAAH) is mediated by CB1 receptors. Neuropharmacology 54:141-150.

Morena M, Patel S, Bains JS, and Hill MN (2016) Neurobiological interactions between stress and the endocannabinoid system. Neuropsychopharmacology 41:80-102.

Müller CA, Geisel O, Banas R, and Heinz A (2014) Current pharmacological treatment approaches for alcohol dependence. Expert Opin Pharmacother 15:471-481.

Naassila M, Pierrefiche O, Ledent C, and Daoust M (2004) Decreased alcohol selfadministration and increased alcohol sensitivity and withdrawal in CB1 receptor knockout mice. Neuropharmacology 46:243-253.

Navarro M, Cubero I, and Thiele TE (2013) Decreased immunoreactivity of the polypeptide precursor pro-opiomelanocortin (POMC) and the prohormone convertase pc1/3 after chronic ethanol exposure in Sprague-Dawley rats. Alcohol Clin Exp Res 37:399-406.

Nealey KA, Smith AW, Davis SM, Smith DG, and Walker BM (2011) $\kappa$-Opioid receptors are implicated in the increased potency of intra-accumbens nalmefene in ethanol-dependent rats. Neuropharmacology 61:35-42.

Nelson BS, Sequeira MK, and Schank JR (2018) Bidirectional relationship between alcohol intake and sensitivity to social defeat: association with Tacr1 and Avp expression. Addict Biol 23:142-153.

Olive MF, Koenig HN, Nannini MA, and Hodge CW (2001) Stimulation of endorphin neurotransmission in the nucleus accumbens by ethanol, cocaine, and amphetamine. J Neurosci 21:RC184.

Olney JJ, Navarro M, and Thiele TE (2014) Targeting central melanocortin receptors: a promising novel approach for treating alcohol abuse disorders. Front Neurosci 8:128. O'Malley SS, Jaffe AJ, Chang G, Schottenfeld RS, Meyer RE, and Rounsaville B (1992) Naltrexone and coping skills therapy for alcohol dependence. A controlled study. Arch Gen Psychiatry 49:881-887.

O'Malley SS, Krishnan-Sarin S, Farren C, Sinha R, and Kreek MJ (2002) Naltrexone decreases craving and alcohol self-administration in alcohol-dependent subjects and activates the hypothalamo-pituitary-adrenocortical axis. Psychopharmacology (Berl) 160:19-29.

Overstreet DH and Griebel G (2005) Antidepressant-like effects of the vasopressin V1b receptor antagonist SSR149415 in the Flinders Sensitive Line rat. Pharmacol Biochem Behav 82:223-227.

Pang TY, Du X, Catchlove WA, Renoir T, Lawrence AJ, and Hannan AJ (2013) Positive environmental modification of depressive phenotype and abnormal hypothalamic-pituitary-adrenal axis activity in female C57BL/6J mice during abstinence from chronic ethanol consumption. Front Pharmacol 4:93.

Panlilio LV, Justinova Z, and Goldberg SR (2013) Inhibition of FAAH and activation of PPAR: new approaches to the treatment of cognitive dysfunction and drug addiction. Pharmacol Ther 138:84-102.

Parsons LH and Hurd YL (2015) Endocannabinoid signalling in reward and addiction. Nat Rev Neurosci 16:579-594.

Partonen T (2015) Clock genes in human alcohol abuse and comorbid conditions. Alcohol 49:359-365.

Pascoe JE, Williams KL, Mukhopadhyay P, Rice KC, Woods JH, and Ko MC (2008) Effects of mu, kappa, and delta opioid receptor agonists on the function of hypothalamic-pituitary-adrenal axis in monkeys. Psychoneuroendocrinology 33: 478-486.

Pastor R, Font L, Miquel M, Phillips TJ, and Aragon CM (2011) Involvement of the beta-endorphin neurons of the hypothalamic arcuate nucleus in ethanol-induced place preference conditioning in mice. Alcohol Clin Exp Res 35:2019-2029.

Pomrenze MB, Fetterly TL, Winder DG, and Messing RO (2017) The corticotropin releasing factor receptor 1 in alcohol use disorder: still a valid drug target? Alcohol Clin Exp Res 41:1986-1999.

Qi X, Guzhva L, Ji Y, and Bruijnzeel AW (2015) Chronic treatment with the vasopressin $1 \mathrm{~b}$ receptor antagonist SSR149415 prevents the dysphoria associated with nicotine withdrawal in rats. Behav Brain Res 292:259-265.

Racz I, Schürmann B, Karpushova A, Reuter M, Cichon S, Montag C, Fürst R, Schütz C, Franke PE, Strohmaier J, et al. (2008) The opioid peptides enkephalin and betaendorphin in alcohol dependence. Biol Psychiatry 64:989-997.

Rademacher DJ and Hillard CJ (2007) Interactions between endocannabinoids and stress-induced decreased sensitivity to natural reward. Prog Neuropsychopharmacol Biol Psychiatry 31:633-641.
Ragavan VV, Wardlaw SL, Kreek MJ, and Frantz AG (1983) Effect of chronic naltrexone and methadone administration on brain immunoreactive beta-endorphin in the rat. Neuroendocrinology 37:266-268.

Rasmussen DD, Boldt BM, Wilkinson CW, and Mitton DR (2002) Chronic daily ethanol and withdrawal: 3. Forebrain pro-opiomelanocortin gene expression and implications for dependence, relapse, and deprivation effect. Alcohol Clin Exp Res 26:535-546.

Reed B, Butelman ER, Fry RS, Kimani R, and Kreek MJ (2018) Repeated administration of opra kappa (LY2456302), a novel, short-acting, selective KOP-r antagonist, in persons with and without cocaine dependence. Neuropsychopharmacology 43:739-750.

Rhodes JS, Best K, Belknap JK, Finn DA, and Crabbe JC (2005) Evaluation of a simple model of ethanol drinking to intoxication in C57BL/6J mice. Physiol Behav 84:53-63.

Richardson HN, Lee SY, O’Dell LE, Koob GF, and Rivier CL (2008) Alcohol selfadministration acutely stimulates the hypothalamic-pituitary-adrenal axis, but alcohol dependence leads to a dampened neuroendocrine state. Eur J Neurosci 28: 1641-1653

Rigter H and Crabbe JC (1985) Vasopressin and ethanol preference. I. Effects of vasopressin and the fragment DGAVP on altered ethanol preference in Brattleboro diabetes insipidus rats. Peptides 6:669-676.

Rivier C and Vale W (1988) Interaction between ethanol and stress on ACTH and beta-endorphin secretion. Alcohol Clin Exp Res 12:206-210.

Roberts AJ, McDonald JS, Heyser CJ, Kieffer BL, Matthes HW, Koob GF, and Gold LH (2000) $\mu$-Opioid receptor knockout mice do not self-administer alcohol. $J$ Pharmacol Exp Ther 293:1002-1008.

Robinson SL and Thiele TE (2017) The role of neuropeptide Y (NPY) in alcohol and drug abuse disorders. Int Rev Neurobiol 136:177-197.

Romanova EV, Rubakhin SS, Ossyra JR, Zombeck JA, Nosek MR, Sweedler JV, and Rhodes JS (2015) Differential peptidomics assessment of strain and age dif ferences in mice in response to acute cocaine administration. $J$ Neurochem 135: $1038-1048$

Roper J, O'Carroll AM, Young W, III, and Lolait S (2011) The vasopressin Avpr1b receptor: molecular and pharmacological studies. Stress 14:98-115.

Rorick-Kehn LM, Witkin JM, Statnick MA, Eberle EL, McKinzie JH, Kahl SD, Forster BM, Wong CJ, Li X, Crile RS, et al. (2014) LY2456302 is a novel, potent, orally-bioavailable small molecule kappa-selective antagonist with activity in animal models predictive of efficacy in mood and addictive disorders. Neuropharmacology 77:131-144.

Rose JH, Karkhanis AN, Chen R, Gioia D, Lopez MF, Becker HC, McCool BA, and Jones SR (2016) Supersensitive kappa opioid receptors promotes ethanol withdrawal-related behaviors and reduce dopamine signaling in the nucleus accumbens. Int $J$ Neuropsychopharmacol 19:1-10.

Roth-Deri I, Green-Sadan T, and Yadid G (2008) Beta-endorphin and drug-induced reward and reinforcement. Prog Neurobiol 86:1-21.

Rubinstein M, Mogil JS, Japón M, Chan EC, Allen RG, and Low MJ (1996) Absence of opioid stress-induced analgesia in mice lacking beta-endorphin by site-directed mutagenesis. Proc Natl Acad Sci USA 93:3995-4000.

Ryan ML, Falk DE, Fertig JB, Rendenbach-Mueller B, Katz DA, Tracy KA, Strain EC, Dunn KE, Kampman K, Mahoney E, et al. (2017) A phase 2, double-blind, placebo-controlled randomized trial assessing the efficacy of ABT-436, a novel V1b receptor antagonist, for alcohol dependence. Neuropsychopharmacology 42: $1012-1023$.

Salomé N, Stemmelin J, Cohen C, and Griebel G (2006) Differential roles of amygdaloid nuclei in the anxiolytic- and antidepressant-like effects of the V1b receptor antagonist, SSR149415, in rats. Psychopharmacology (Berl) 187:237-244.

Schank JR, Goldstein AL, Rowe KE, King CE, Marusich JA, Wiley JL, Carroll FI, Thorsell A, and Heilig M (2012) The kappa opioid receptor antagonist JDTic attenuates alcohol seeking and withdrawal anxiety. Addict Biol 17:634-647.

Schattauer SS, Kuhar JR, Song A, and Chavkin C (2017) Nalfurafine is a G-protein biased agonist having significantly greater bias at the human than rodent form of the kappa opioid receptor. Cell Signal 32:59-65.

Schluger JH, Ho A, Borg L, Porter M, Maniar S, Gunduz M, Perret G, King A, and Kreek MJ (1998) Nalmefene causes greater hypothalamic-pituitary-adrenal axis activation than naloxone in normal volunteers: implications for the treatment of alcoholism. Alcohol Clin Exp Res 22:1430-1436.

Schuckit MA (1994) Low level of response to alcohol as a predictor of future alcoholism. Am J Psychiatry 151:184-189.

Serradeil-Le Gal C, Wagnon J, Simiand J, Griebel G, Lacour C, Guillon G, Barberis C, Brossard G, Soubrié P, Nisato D, et al. (2002) Characterization of $(2 S, 4 R)$-1-[5 chloro-1-[(2,4-dimethoxyphenyl)sulfonyl]-3-(2-methoxy-phenyl)-2-oxo-2,3-dihydro$1 H$-indol-3-yl]-4-hydroxy- $N, N$-dimethyl-2-pyrrolidine carboxamide (SSR149415), a selective and orally active vasopressin V1b receptor antagonist. J Pharmacol Exp Ther 300:1122-1130.

Serrano A, Rivera P, Pavon FJ, Decara J, Suárez J, Rodriguez de Fonseca F, and Parsons LH (2012) Differential effects of single versus repeated alcohol withdrawal on the expression of endocannabinoid system-related genes in the rat amygdala. Alcohol Clin Exp Res 36:984-994.

Shelkar GP, Kale AD, Singh U, Singru PS, Subhedar NK, and Kokare DM (2015) Alphamelanocyte stimulating hormone modulates ethanol self-administration in posterior ventral tegmental area through melanocortin-4 receptors. Addict Biol 20:302-315.

Shippenberg TS, Zapata A, and Chefer VI (2007) Dynorphin and the pathophysiology of drug addiction. Pharmacol Ther 116:306-321.

Silva SM, Madeira MD, Ruela C, and Paula-Barbosa MM (2002) Prolonged alcohol intake leads to irreversible loss of vasopressin and oxytocin neurons in the paraventricular nucleus of the hypothalamus. Brain Res 925:76-88.

Simms JA, Steensland P, Medina B, Abernathy KE, Chandler LJ, Wise R, and Bartlett SE (2008) Intermittent access to $20 \%$ ethanol induces high ethanol consumption in Long-Evans and Wistar rats. Alcohol Clin Exp Res 32:1816-1823. 
Simonson B, Morani AS, Ewald AW, Walker L, Kumar N, Simpson D, Miller JH, Prisinzano TE, and Kivell BM (2015) Pharmacology and anti-addiction effects of the novel $\kappa$ opioid receptor agonist Mesyl Sal B, a potent and long-acting analogue of salvinorin A. Br J Pharmacol 172:515-531.

Sipe JC, Chiang K, Gerber AL, Beutler E, and Cravatt BF (2002) A missense mutation in human fatty acid amide hydrolase associated with problem drug use. Proc Natl Acad Sci USA 99:8394-8399.

Sirohi S, Aldrich JV, and Walker BM (2016) Species differences in the effects of the $\kappa$-opioid receptor antagonist zyklophin. Alcohol 51:43-49.

Sloan ME, Gowin JL, Ramchandani VA, Hurd YL, and Le Foll B (2017) The endocannabinoid system as a target for addiction treatment: trials and tribulations. Neuropharmacology 124:73-83.

Sloan ME, Gowin JL, Yan J, Schwandt ML, Spagnolo PA, Sun H, Hodgkinson CA, Goldman D, and Ramchandani VA (2018) Severity of alcohol dependence is associated with the fatty acid amide hydrolase Pro129Thr missense variant. Addict Biol 23:474-484.

Spanagel R, Herz A, Bals-Kubik R, and Shippenberg TS (1991) Beta-endorphin-induced locomotor stimulation and reinforcement are associated with an increase in dopamine release in the nucleus accumbens. Psychopharmacology (Berl) 104:51-56.

Spanagel R, Pendyala G, Abarca C, Zghoul T, Sanchis-Segura C, Magnone MC, Lascorz J, Depner M, Holzberg D, Soyka M, et al. (2005) The clock gene Per2 influences the glutamatergic system and modulates alcohol consumption. Nat Med 11:35-42.

Sperling RE, Gomes SM, Sypek EI, Carey AN, and McLaughlin JP (2010) Endogenous kappa-opioid mediation of stress-induced potentiation of ethanol-conditioned place preference and self-administration. Psychopharmacology (Berl) 210:199-209.

Spierling SR and Zorrilla EP (2017) Don't stress about CRF: assessing the translational failures of $\mathrm{CRF}_{1}$ antagonists. Psychopharmacology (Berl) 234:1467-1481.

Sprow GM, Rinker JA, Lowery-Gointa EG, Sparrow AM, Navarro M, and Thiele TE (2016) Lateral hypothalamic melanocortin receptor signaling modulates binge-like ethanol drinking in C57BL/6J mice. Addict Biol 21:835-846.

Stopponi S, Fotio Y, Domi A, Borruto AM, Natividad L, Roberto M, Ciccocioppo R, and Cannella N (2018) Inhibition of fatty acid amide hydrolase in the central amygdala alleviates co-morbid expression of innate anxiety and excessive alcohol intake. Addict Biol DOI: 10.1111/adb.12573 [published ahead of print].

Sushchyk S, Xi ZX, and Wang JB (2016) Combination of levo-tetrahydropalmatine and low dose naltrexone: a promising treatment for prevention of cocaine relapse. $J$ Pharmacol Exp Ther 357:248-257.

Townsend EA, Naylor JE, Negus SS, Edwards SR, Qureshi HN, McLendon HW, McCurdy CR, Kapanda CN, do Carmo JM, da Silva FS, et al. (2017) Effects of nalfurafine on the reinforcing, thermal antinociceptive, and respiratory-depressant effects of oxycodone: modeling an abuse-deterrent opioid analgesic in rats. Psychopharmacology (Berl) 234:2597-2605.

Trabert W, Caspari D, Bernhard P, and Biro G (1992) Inappropriate vasopressin secretion in severe alcohol withdrawal. Acta Psychiatr Scand 85:376-379.

Tunstall BJ, Carmack SA, Koob GF, and Vendruscolo LF (2017) Dysregulation of brain stress systems mediates compulsive alcohol drinking. Curr Opin Behav Sci 13:85-90.

Ur E, Wright DM, Bouloux PM, and Grossman A (1997) The effects of spiradoline (U$62066 \mathrm{E})$, a kappa-opioid receptor agonist, on neuroendocrine function in man. $B r J$ Pharmacol 120:781-784

Vaccari C, Lolait SJ, and Ostrowski NL (1998) Comparative distribution of vasopressin V1b and oxytocin receptor messenger ribonucleic acids in brain. Endocrinology 139:5015-5033.

Vale W, Spiess J, Rivier C, and Rivier J (1981) Characterization of a 41-residue ovine hypothalamic peptide that stimulates secretion of corticotropin and beta-endorphin. Science 213:1394-1397.

van Ree JM, Gerrits MA, and Vanderschuren LJ (1999) Opioids, reward and addiction: an encounter of biology, psychology, and medicine. Pharmacol Rev 51:341-396.

Varodayan FP, Soni N, Bajo M, Luu G, Madamba SG, Schweitzer P, Parsons LH, and Roberto M (2016) Chronic ethanol exposure decreases CB1 receptor function at GABAergic synapses in the rat central amygdala. Addict Biol 21:788-801.

Veinante P and Freund-Mercier MJ (1997) Distribution of oxytocin- and vasopressinbinding sites in the rat extended amygdala: a histoautoradiographic study. J Comp Neurol 383:305-325.

Volpicelli JR, Alterman AI, Hayashida M, and O'Brien CP (1992) Naltrexone in the treatment of alcohol dependence. Arch Gen Psychiatry 49:876-880.

Walker BM and Koob GF (2008) Pharmacological evidence for a motivational role of kappa-opioid systems in ethanol dependence. Neuropsychopharmacology $\mathbf{3 3}$ $643-652$

Wand GS, McCaul M, Yang X, Reynolds J, Gotjen D, Lee S, and Ali A (2002) The mu-opioid receptor gene polymorphism (A118G) alters HPA axis activation induced by opioid receptor blockade. Neuropsychopharmacology 26:106-114.

Wang L, Liu J, Harvey-White J, Zimmer A, and Kunos G (2003) Endocannabinoid signaling via cannabinoid receptor 1 is involved in ethanol preference and its agedependent decline in mice. Proc Natl Acad Sci USA 100:1393-1398.

Wee S and Koob GF (2010) The role of the dynorphin-kappa opioid system in the reinforcing effects of drugs of abuse. Psychopharmacology (Berl) 210:121-135.

Wernet W, Hornberger WB, Unger LV, et al. (2008) In vitro characterization of the selective vasopressin $\mathrm{V}_{1 \mathrm{~B}}$ receptor antagonists ABT-436 and ABT-558. Proc Soc Neurosci 560:16.

White KL, Robinson JE, Zhu H, DiBerto JF, Polepally PR, Zjawiony JK, Nichols DE, Malanga CJ, and Roth BL (2015) The G protein-biased $\kappa$-opioid receptor agonist
RB-64 is analgesic with a unique spectrum of activities in vivo. $J$ Pharmacol Exp Ther 352:98-109.

Wigger A, Sánchez MM, Mathys KC, Ebner K, Frank E, Liu D, Kresse A, Neumann ID, Holsboer F, Plotsky PM, et al. (2004) Alterations in central neuropeptide expression, release, and receptor binding in rats bred for high anxiety: critical role of vasopressin. Neuropsychopharmacology 29:1-14.

Winkler A, Roske I, Furkert J, Fickel J, and Melzig MF (1995) Effects of voluntary ethanol ingestion on the POMC gene expression in the rat pituitary and on the plasma beta-endorphin content. Alcohol Alcohol 30:231-238.

Wise RA (1973) Voluntary ethanol intake in rats following exposure to ethanol on various schedules. Psychopharmacology (Berl) 29:203-210.

Yoo JH, Kitchen I, and Bailey A (2012) The endogenous opioid system in cocaine addiction: what lessons have opioid peptide and receptor knockout mice taught us? Br J Pharmacol 166:1993-2014.

Young WS, Li J, Wersinger SR, and Palkovits M (2006) The vasopressin 1b receptor is prominent in the hippocampal area $\mathrm{CA} 2$ where it is unaffected by restraint stress or adrenalectomy. Neuroscience 143:1031-1039.

Zhou Y, Bendor JT, Yuferov V, Schlussman SD, Ho A, and Kreek MJ (2005) Amygdalar vasopressin mRNA increases in acute cocaine withdrawal: evidence for opioid receptor modulation. Neuroscience 134:1391-1397.

Zhou Y, Colombo G, Carai MAM, Ho A, Gessa GL, and Kreek MJ (2011) Involvement of arginine vasopressin and V1b receptor in alcohol drinking in Sardinian alcoholpreferring rats. Alcohol Clin Exp Res 35:1876-1883.

Zhou Y, Colombo G, Gessa GL, and Kreek MJ (2013a) Effects of voluntary alcohol drinking on corticotropin-releasing factor and preprodynorphin mRNA levels in the central amygdala of Sardinian alcohol-preferring rats. Neurosci Lett 554: 110-114.

Zhou Y, Colombo G, Niikura K, Carai MAM, Femenía T, García-Gutiérrez MS, Manzanares J, Ho A, Gessa GL, and Kreek MJ (2013b) Voluntary alcohol drinking enhances proopiomelanocortin gene expression in nucleus accumbens shell and hypothalamus of Sardinian alcohol-preferring rats. Alcohol Clin Exp Res 37 (Suppl 1): E131-E140.

Zhou Y, Crowley RS, Ben K, Prisinzano TE, and Kreek MJ (2017a) Synergistic blockade of alcohol escalation drinking in mice by a combination of novel kappa opioid receptor agonist Mesyl Salvinorin B and naltrexone. Brain Res 1662:75-86.

Zhou Y, Crowley R, Prisinzano T, and Kreek MJ (2018b) Effects of mesyl salvinorin $\mathrm{B}$ alone and in combination with naltrexone on alcohol deprivation effect in male and female mice. Neurosci Lett 673:19-23.

Zhou Y, Franck J, Spangler R, Maggos CE, Ho A, and Kreek MJ (2000) Reduced hypothalamic POMC and anterior pituitary CRF1 receptor mRNA levels after acute, but not chronic, daily "binge" intragastric alcohol administration. Alcohol Clin Exp Res 24:1575-1582.

Zhou Y, Huang T, Lee F, and Kreek MJ (2016) Involvement of endocannabinoids in alcohol "binge" drinking: studies of mice with human fatty acid amide hydrolase genetic variation and after CB1 receptor antagonists. Alcohol Clin Exp Res 40:467-473.

Zhou Y and Kreek MJ (2014) Alcohol: a stimulant activating brain stress responsive systems with persistent neuroadaptation. Neuropharmacology 87:51-58.

Zhou Y and Kreek MJ (2018) Human kappa opioid receptor (KOP-r) partial agonist nalmefene and agonist nalfurafine reduce excessive and "relapse" alcohol drinking in C57BL/6J mice. CPDD 80th Annual Scientific Meeting; 2018 June 9-14; San Diego, CA; College on Problem of Drug Dependence (CPDD), Philadelphia, PA.

Zhou Y and Leri F (2016) Neuroscience of opiates for addiction medicine: from stressresponsive systems to behavior. Prog Brain Res 223:237-251.

Zhou Y, Leri F, Cummins E, Hoeschele M, and Kreek MJ (2008) Involvement of arginine vasopressin and V1b receptor in heroin withdrawal and heroin seeking precipitated by stress and by heroin. Neuropsychopharmacology 33:226-236.

Zhou Y, Leri F, Grella SL, Aldrich JV, and Kreek MJ (2013c) Involvement of dynorphin and kappa opioid receptor in yohimbine-induced reinstatement of heroin seeking in rats. Synapse 67:358-361.

Zhou Y, Rubinstein M, Low MJ, and Kreek MJ (2017c) Hypothalamic-specific proopiomelanocortin deficiency reduces alcohol drinking in male and female mice. Genes Brain Behav 16:449-461.

Zhou Y, Rubinstein M, Low MJ, and Kreek MJ (2018a) V1b receptor antagonist SSR149415 and naltrexone synergistically decrease excessive alcohol drinking in male and female mice. Alcohol Clin Exp Res 42:195-205.

Zhou Y, Schwartz BI, Giza J, Gross SS, Lee FS, and Kreek MJ (2017d) Blockade of alcohol escalation and "relapse" drinking by pharmacological FAAH inhibition in male and female C57BL/6J mice. Psychopharmacology (Berl) 234:2955-2970.

Zhou Y, Spangler R, LaForge KS, Maggos CE, Ho A, and Kreek MJ (1996) Modulation of CRF-R1 mRNA in rat anterior pituitary by dexamethasone: correlation with POMC mRNA. Peptides 17:435-441.

Zimmermann U, Hundt W, Spring K, Grabner A, and Holsboer F (2003) Hypothalamicpituitary-adrenal system adaptation to detoxification in alcohol-dependent patients is affected by family history of alcoholism. Biol Psychiatry 53:75-84.

Zorrilla EP, Valdez GR, and Weiss F (2001) Changes in levels of regional CRF-likeimmunoreactivity and plasma corticosterone during protracted drug withdrawal in dependent rats. Psychopharmacology (Berl) 158:374-381.

Address correspondence to: Dr. Yan Zhou, Laboratory of the Biology of Addictive Diseases, The Rockefeller University, 1230 York Avenue, New York, NY 10065. E-mail: zhouya@rockefeller.edu 